NBER WORKING PAPER SERIES

\title{
THE SHOCK OF FALLING AMONG OLDER AMERICANS
}

\author{
Inas Rashad Kelly \\ Working Paper 23517 \\ http://www.nber.org/papers/w23517 \\ NATIONAL BUREAU OF ECONOMIC RESEARCH \\ 1050 Massachusetts Avenue \\ Cambridge, MA 02138 \\ June 2017
}

The author thanks Steven Flamer for research assistance. The author thanks Kelly Noonan, participants at the 2015 Eastern Economic Association meetings, seminar participants at California State University at Long Beach, and seminar participants at the University of Southern California for helpful comments. The author alone is responsible for errors. The views expressed herein are those of the author and do not necessarily reflect the views of the National Bureau of Economic Research.

NBER working papers are circulated for discussion and comment purposes. They have not been peer-reviewed or been subject to the review by the NBER Board of Directors that accompanies official NBER publications.

(C) 2017 by Inas Rashad Kelly. All rights reserved. Short sections of text, not to exceed two paragraphs, may be quoted without explicit permission provided that full credit, including (C) notice, is given to the source. 
The Shock of Falling Among Older Americans

Inas Rashad Kelly

NBER Working Paper No. 23517

June 2017

JEL No. I1

\begin{abstract}
$\underline{\text { ABSTRACT }}$
Direct medical costs associated with falls have been shown to be $\$ 34$ billion in 2013, an underestimate since full costs are not factored in. Using the 1998-2012 waves of the Health and Retirement Study and several econometric methods to address the endogeneity of falls, this study seeks to answer the question of how much worse physical and mental health outcomes are for individuals who fall compared to their steadier counterparts. Results across various specifications suggest that falling leads to lower activities of daily living, more depression, and more psychological problems. It leads to greater probabilities of being in poor health, having heart problems, and having a stroke. These results survive several robustness checks.
\end{abstract}

Inas Rashad Kelly

Queens College, CUNY

Economics Department

300 Powdermaker Hall

65-30 Kissena Boulevard

Flushing, NY 11367

and NBER

Inas.Kelly@qc.cuny.edu 
The single most serious threat she faced was not the lung nodule or the back pain. It was falling. Each year, about 350,000 Americans fall and break a hip. Of those, 40 percent end up in a nursing home, and 20 percent are never able to walk again. -p40, Being Mortal, by Atul Gawande

\section{Introduction}

According to data from the Web-based Injury Statistics Query and Reporting System (WISQARS), the number of deaths from falls among individuals 65 years of age and older in the United States rose from 10,227 in 1999 to 25,593 in 2013. Direct medical costs associated with falls were estimated to be $\$ 34$ billion in 2013 (CDC 2015). The National Council on Aging and other organizations are promoting a National Falls Prevention Action Plan, yet the importance of preventing falls among older Americans has been stressed in the past (Alexander et al. 1992). Falling can not only lead to disability, loss of independence, and admission to nursing homes, but a stay at the hospital after falling can bring on other ailments. ${ }^{1}$ What takes seconds to occur can lead to dire consequences. That being said, the type of fall is important: whether the fall resulted in an injury, for example, whether the individual fell for the first time, and the number of falls an individual has experienced prior to the fall all play a role in the severity of the outcomes in question.

According to the United States Census Bureau, people 65 years of age and older made up $14.5 \%(46,243,211 / 318,857,056)$ of the population in $2014 .^{2}$ Falls among older individuals can result in direct injury and medical costs due to the fall. They may also result in death, disability, nursing-home admission, prolonged hospitalization, or indirect medical issues and costs (Stevens 2006; Bell et al. 2000). Direct medical care costs totaled $\$ 0.2$ billion for fatal and $\$ 19.2$ billion for non-fatal fall related injuries among people over the age of 65 (Stevens et al. 2006). These figures

\footnotetext{
${ }^{1}$ To prevent further falls, hospital staff members often keep an individual from moving around, which has adverse effects on health (such as through bed sores or muscle atrophy, in addition to adverse psychological effects), potentially increasing the probability of falling and of morbidity and mortality in the future. Patients who stay in bed do not use their lungs as much, which may lead to pneumonia and lung infections (Resnick 2013). There is also the concern of iatrogenic illnesses; for example, patients, particularly older female patients, can develop ST-elevation myocardial infarction (STEMI) while hospitalized for a noncardiac condition (Dai et al. 2013).

${ }^{2}$ Data obtained from http://factfinder.census.gov/faces/tableservices/jsf/pages/productview.xhtml? src=bkmk.
} 
reflect what patients and insurance companies pay and do not include indirect costs associated with poor subsequent physical and mental health outcomes; thus, the full costs associated with falls among older individuals are much higher. Figure 1 shows proposed mechanisms.

A fall for an older individual can be a shock, as it happens so quickly and can be fatal (Sterling et al. 2001), yet it has the potential to be relatively easy to prevent if it means providing funding for home modification measures. Falling is not a shock in the sense that it has an endogenous quality to it, and not all older individuals are equally likely to fall. It is a symptom of an issue with postural stability and causes can be complex. Statistical endogeneity arises when analyzing the effect of falling on health outcomes and mortality due to unobserved heterogeneity. Structural endogeneity may arise as poor health may increase the probability of falling. Yet given two otherwise identical individuals, one who falls suffers worse outcomes in the subsequent years. Estimating the magnitudes of these outcomes employing appropriate sources of identification is the main goal of this study. Using the 1998-2012 waves of the Health and Retirement Study and several econometric methods, this study seeks to answer the question of how much worse physical and mental health outcomes are for older individuals who have experienced a fall. Hazard models predicting the probability of death after a fall are also run. Aside from estimating direct costs of falls, health economists do not appear to have analyzed the causal effect of falls on physical and mental health outcomes. This study seeks to fill this critical gap in the literature.

\section{Empirical Implementation}


The empirical methodology begins with the following specification for predicting the probability of falling, the number of falls, and the probability of falling and injuring oneself for individual $i$ in Census division $d$ in year of survey $t:^{3}$

$$
\text { Fall }_{i d t}=a_{0}+a_{1} X_{i t}+\mu_{i}+\varepsilon_{1 i d t}
$$

Where $X$ is a vector of individual-level variables pertaining to gender, age, number of living parents, race/ethnicity, education, marital status, household income, number of children, veteran status, and Census division. Extended models include information on behavioral variables pertaining to prescription drug use, obesity, alcohol consumption, and smoking, in addition to medical variables pertaining to arthritis and physician use. ${ }^{4}$ This model is estimated using individual fixed effects $\mu_{i}$, and $\varepsilon_{1 i d t}$ is an error term. Models where the falling variable is limited to those with more than one fall are also estimated, since it has been found that the perceived risks for those who fall only one time tend to be exaggerated (Donald and Bulpitt 1999). ${ }^{5}$

The following health production function is then estimated:

$$
\text { Health Outcome } \text { idt }=\beta_{0}+\beta_{1} \text { Fall }_{i d t}+\beta_{2} X_{\text {idt }}+\mu_{i}+\varepsilon_{2 i d t}
$$

Where the health outcome of interest is one of the following: good health ( $=1$ if the individual selfreports him- or herself as being in excellent, very good, or good health), a summary measure for Activities of Daily Living (ADL, such as walking across a room, dressing, bathing, eating, getting out of bed, and using the toilet), presence of heart problems, whether the individual had a stroke since

\footnotetext{
${ }^{3}$ It is tempting to focus the analysis only on falls that result in injury, since those are the more relevant. Doing so, however, would be problematic for at least two reasons: (1) Falling, even without injury, can affect mental health and render a person less likely to engage in physical activity, for example, for fear of falling again, and (2) Whether someone gets injured due to a fall is endogenous.

${ }^{4}$ Results are robust to the inclusion of the following potentially endogenous variables: being in a nursing home, employment, years worked, and home care. These results are available upon request. About 3\% of the sample is in a nursing home, $25 \%$ are employed, and $8 \%$ receive home care.

${ }^{5}$ Models were run including osteoporosis (available only in 2012) on the RHS, as this may be a strong predictor of frailty and falling in turn. These results are similar and are available upon request.
} 
the previous survey, depression as measured by the Center for Epidemiologic Studies - Depression (CESD) scale, ${ }^{6}$ a summary of psychological problems, and the presence of cancer, which can serve as an imperfect robustness check. Linear probability models are run for all health outcomes; for dichotomous outcomes, probit models yield similar results.

Physical health outcomes pertaining to self-reported health, ADL, heart problems, and stroke were chosen mainly due to the direct and indirect effects of falling on subsequent immobility and physical inactivity, which are major risk factors for these outcomes. Mental health outcomes pertaining to depression and psychological problems were chosen partially due to the effects of falling on physical inactivity (strongly correlated with mental health) and partially due to the fear of falling and realization/impression (whether or not accurate) that one's health is deteriorating. Moreover, the effects on physical health affect an individual's mental health. Traumatic brain injuries are a particular concern among older individuals who fall (Jager et al. 2000). ${ }^{7}$

As additional robustness checks, shown in Appendix Table 3, the following models are run: (1) lagged falls, (2) more than one fall, (3) attrition accounted for using inverse probability weighting (IPW), as in Dave et al. (2008), and (4) pseudo falls as a falsification check. ${ }^{8}$ Models are also estimated separately by gender, as significant differences across gender have been cited (Stevens and

\footnotetext{
${ }^{6}$ The CESD scale, with a range from 0 to 8 , measures negative mental health symptoms for the week prior to being surveyed. Questions relate to (1) feeling depressed, (2) feeling everything was an effort, (3) having restless sleep, (4) not being happy, (5) feeling lonely, (6) feeling sad, (7) not being able to get going, and (8) not enjoying life. ${ }^{7}$ It can be argued that self-reported health and depression might better capture the respondent's state at the time of interview, since temporal precedence is clear in these cases. That being said, robustness checks which include lagged falls are run, results of which are presented in Appendix Table 3.

${ }^{8}$ Pseudo-falling is defined such that an individual who fell for the first time in one wave is falsely assigned falling in a previous wave. Pseudo-falling should have no causal adverse effect on health outcomes.
} 
Sogolow 2005), in addition to being estimated separately by marital status and age group (Appendix Table 4). ${ }^{9}$ Appendix Table 5 presents results from nonlinear specifications for the number of falls.

Addressing the potential endogeneity of falls is not an easy task, and the following methods are employed in additional to the robustness checks listed above: (1) stepwise estimation, in which covariates are gradually added to the baseline model, (2) individual fixed effects models, which address unobserved heterogeneity but have the potential to eliminate much variation, (3) instrumental variables (employing internal instruments à la Lewbel 2012), (4) falsification checks using outcomes for which we would not expect to see an effect, such as cancer, and (5) propensity score matching.

Next, a Weibull hazard model is estimated for the probability of death. ${ }^{10}$ Hazard ratios from the following model are reported:

$$
\lambda(t)=\lambda p(\lambda t)^{p-1}
$$

Where $t$ is time and $p$ is a scale parameter. If $p$ is greater than one, position duration dependence is exhibited, suggesting that death is more likely to occur at time $t$ given that the individual has been alive up until time $t$. (Therefore $d \lambda / d t>0$.) Results indicate that this is indeed the case, as the value of $p$ is 1.453 .

\section{Stepwise Estimation}

To test the sensitivity of the coefficient on falling, gradually adding covariates is an appropriate empirical strategy. Should the inclusion of individual characteristics substantially reduce the

\footnotetext{
${ }^{9}$ All results are also robust to the inclusion of Census region $\mathrm{x}$ year of survey interaction terms, which may address factors such as differences in the state of the economy across regions over time. These results are available upon request.

${ }^{10}$ Cox and exponential distributions are also estimated; as seen in Table 6, results are not materially affected by choice of distribution for the hazard model.
} 
relationship between falling and health outcomes, we can infer that these characteristics may be driving the observed correlations. Scott and Peck (2004) have identified several factors that determine falls that may cloud the relationship between falls and health outcomes.

Biological Factors: These include: Age: Those over age 80 are significantly more likely to fall and be injured. (See Figures 2 and 3.) Gender: Medical expenditures for female fall patients were two to three times greater than medical expenditures for male fall patients in 2000 , even though females only made up 58\% of the elderly population (Stevens et al. 2006; Stevens et al. 2012). Number of living parents: This variable serves as a proxy for genetic factors.

Social and Economic Risk Factors: These include race/ethnicity (Stevens and Dellinger 2002), education, marital status (which may reflect social connectedness), income, number of children, veteran status, and housing (whether in a nursing home and Census division). Veteran status is included to account for the more generous VA insurance available to veterans. ${ }^{11}$

Behavioral Risk Factors: These include medication use (Lawlor et al. 2003), ${ }^{12}$ inadequate diet/exercise (obesity), risk-taking behaviors (such as alcohol use and smoking), and employment variables (which can arguably also be placed in the above set of factors). ${ }^{13}$

Medical Factors: These include physical disability or diminished physical fitness, the presence of arthritis, physician use, and home care use.

\footnotetext{
${ }_{11}$ Almost all individuals in the sample have some form of health insurance, most in the form of Medicare. Results including insurance status, available from the author upon request, are materially unaffected.

12 Prescription drug use is associated with falls due to the side effects, particularly those relating to drowsiness (Cameron 2005). Modifying medication use can aid in reducing falls.

${ }^{13}$ Vision loss is also associated with falls and strongly correlated with age and health (Lord et al. 2010). Vision loss, through age-related conditions such as cataracts, age-related macular degeneration, diabetic retinopathy, and glaucoma, can cause falls through reduced contrast sensitivity, reduced depth perception, and reduced visual field (Steinman 2017). Results predicting falling controlling for an extended set of covariates suggest that those with good, very good, or excellent eyesight are 9.47 percentage points less likely to fall. Results from health outcome models that control for poor eyesight (affecting 20\% of the sample) reveal little or no difference in the coefficients of interest and are available from the author upon request. The question is: (Using glasses or corrective lens as usual) How good is your eyesight for seeing things at a distance, like recognizing a friend across the street? (Is it excellent, very good, good, fair, or poor?)
} 
Models are initially run utilizing a limited, more exogenous set of covariates, which include controls for gender, age, and number of living parents. Extended models are then run adding race/ethnic status, education, marital status, income, number of children, veteran status, use of prescription drugs, obesity, alcohol consumption, smoking status, arthritis, physician use, year of survey, and Census division. Additional models are run (results not reported) with nursing home status, employment, years worked, and home care use.

\section{Instrumental Variables}

Lewbel (2012) has devised a technique whereby internal instruments are generated when external instruments are weak or unavailable. In this context, it is difficult to find external instruments that pass the necessary tests. ${ }^{14}$ The technique put forth by Lewbel (2012) relies on higher order variation as reflected by the presence of heteroscedasticity in the error term of the first-stage equation, which is tested using a Breusch-Pagan (1979) test. The Lewbel IV procedure uses the deviations from the means of the independent variables multiplied by the predicted residuals from the first-stage regression as instrumental variables. In other words, it employs $(X-\bar{X}) * \varepsilon_{1 i d t}$ as identifying instruments, where $X$ is a vector of all independent variables or a subset of them and $\varepsilon_{1}$ is the predicted residual from the first-stage (falling) regression. Researchers that have successfully used this technique find the Lewbel IV results to be more plausible than ones using questionable external instruments (Sabia 2007; Kelly and Markowitz 2009; Belfield and Kelly 2012). In this context, the variability in falling among certain groups can be greater than that in other groups. As a result, the heteroskedasticity that arises due to these differences provides a source of identification that can capture an unobserved inclination toward falling.

\footnotetext{
${ }^{14}$ Several external instrumental variables were experimented with, including climate data (pertaining to heating and cooling degree days to identify changes in falling in case an individual is more or less likely to fall under certain weather conditions) and various spousal variables in the HRS. These instrumental variables were found to be weak, as revealed by either low F-statistics for joint significance in the first stage or low p-values for overidentification tests, suggesting that the instruments were not legitimately excludable from the second stage.
} 


\section{Propensity Score Analysis}

Propensity score matching may be used to determine the average effect of the treatment (falling) on the treated (health outcomes). The probability of being in poor health given pretreatment characteristics is estimated, and the assumption that the effect of unobservable characteristics on the propensity score is the same as that of observable characteristics is made. This is estimated as:

$$
\begin{gathered}
\tau \equiv E\left\{H_{1}-H_{0} \mid F=1\right\} \\
=E\left\{E\left\{H_{1}-H_{0} \mid F=1, p(W)\right\}\right\} \\
=E\left\{E\left\{H_{1} \mid F=1, p(W)\right\}-E\left\{H_{0}|F=0, p(W)| F=1\right\},\right.
\end{gathered}
$$

Where $\tau$ is the average effect of the treatment on the treated (ATT), $F$ is a binary variable equal to 1 if the individual fell since the previous wave and 0 otherwise, $H$ represents a health outcome, and $W$ is a vector of pretreatment characteristics. The propensity score, $p(W)$, is defined as the probability of falling given pretreatment characteristics $(W)$. Since panel data are employed, the propensity score is calculated using time-invariant characteristics pertaining to race/ethnicity, gender, education, number of children, baseline healthy status (measured in 1992), and veteran status. These covariates satisfy the balancing property in all bloacks. Mahalanobis matching is employed (Leuven and Sianesi 2003; Mahalanobis 1936). ${ }^{15}$ Note that the propensity score matching approach assumes that there is no other confounding factor after many covariates are controlled for (Rosenbaum and Rubin, 1983), a strong assumption. These results should therefore be interpreted in conjunction with several estimation strategies, such as the ones employed in this paper. A formal statistical test for differences in coefficients between IV and propensity score matching is conducted (Clogg et al.

\footnotetext{
${ }^{15}$ Results are not sensitive to the choice of matching method and are robust to other methods such as Kernel (with alternative bandwidths) and radius matching.
} 
1995); these tests generally show few differences in marginal effects using the two alternative approaches.

\section{Data}

\section{Health and Retirement Study (HRS)}

The Health and Retirement Study (HRS) is a longitudinal study conducted through the University of Michigan that surveys a representative sample of approximately 20,000 individuals over the age of 50 in the United States, surveyed every two years. See http://hrsonline.isr.umich.edu/ for more detail. Several cohorts are available, and the HRS cohort (born between 1931 and 1941) is used in this study. The first survey year is 1992, and the most recent one available at the time of this study is 2012. This study employs years 1998-2012, corresponding to eight waves, since questions on falling are first asked in $1996 .{ }^{16}$ The question on falling is: Have you fallen down [since R's LAST IW MONTH, $Y E A R /$ in the last two years] $?^{17}$ If the respondent answered in the affirmative, the following two questions are then asked: How many times have you fallen [since R's LASTIW MONTH, YEAR/in the last two years]? and [In that fall/In any of these falls], did you injure yourself seriously enough to need medical treatment? $^{18}$

Weighted means for HRS variables are shown in Table 1. The average percentage of falls in the sample is $30 \%$, with the average percentage of falls resulting in injury $9 \%$. The sample consists of individuals between 61 and 81 years of age, with an average age of 71 . About $27 \%$ are veterans, and $86 \%$ use prescription drugs.

\footnotetext{
16 That being said, the 1992 survey is used to construct a 'healthy' baseline sample. Models limited to those in good health at baseline (1992), which represents a more exogenous but a selected sample with external validity concerns, yield similar results (and are available upon request).

${ }_{17}$ Since the falling question in 1996 was only asked of individuals 68 years of age and older, these few observations were dropped. (The HRS cohort employed in this study, born between 1931 and 1941, was between the ages of 55 and 65 in 1996.)

18 Unfortunately, information on where the individual fell is not available.
} 


\section{WISQARS}

Fatal injury data from WISQARS is based on the NCHS Vital Statistics System, while nonfatal injury data is based on the NEISS All Injury Program operated by the Consumer Product Safety Commission. Population estimates are obtained from the Census of Population. ${ }^{19}$ These data only report injuries resulting in visits to the emergency room. Figure 2 shows that rates of fatal falls among older Americans have risen from 29.39 per 100,000 population in 1999 to 57.25 per 100,000 population in 2013, a 95\% increase. For nonfatal falls, the rate has risen from 4654.35 in 2001 to 5582.95 in 2013, a 20\% increase (Figure 3). The WISQARS data employed in generating these figures are for individuals 65 years of age and older over time, representing different cohorts.

\section{Results}

Table 2 shows results from regressions predicting falls and falls with injury. Results from probit and fixed effects models are presented. Older individuals are consistently more likely to fall more often with or without a resulting injury, as are individuals who have visited a doctor and those taking prescription drugs. Fixed effects models reveal that the predicted probability of falling for obese individuals is 3.55 percentage points lower, arguably suggesting that excess weight may have a protective effect among older individuals. Appendix Table 1 sheds light on the variation in key variables employed in the FE regressions. Transition probabilities are reported for dichotomous variables. Given that an individual did not fall in one wave, the probability of falling in the subsequent wave, $\mathrm{P}\left(\mathrm{X}_{\mathrm{t}} \mid \mathrm{X}_{\mathrm{t}-1}\right)$ is $21.54 \%$. For obesity, the most likely observed transition is from a nonobese state to an obese one. Given that an individual is nonobese, there is a $6.51 \%$ chance of becoming obese in the next state. Given that a person is obese, there is a $14.7 \%$ chance of

\footnotetext{
${ }^{19}$ See http://www.cdc.gov/injury/wisqars/.
} 
becoming nonobese. As such, there is a chance that the FE result seen in Table 2 is partially driven by those who transit out of obesity.

When limiting the sample to those who have fallen (Appendix Table 2), we see that obese individuals are less likely to have injured themselves as a result of a fall. Males and AfricanAmericans are less likely to fall, which is consistent with the literature.

Table 3 shows results for the effect of falling on various health outcomes. The combination of the various methods helps in arriving at the marginal effect of falling on various health outcomes. The first block shows results for the effect of falling on the probability of being in good health (a self-reported health of excellent, very good, or good). The predicted probability of being in good health is 17.19 percentage points lower for those who fell than for those who did not fall, ceteris paribus (or $23.4 \%$ lower from a mean of $73.5 \%$ individuals in good health). This effect is attenuated somewhat once unobserved heterogeneity is addressed in FE models; it falls to 3.9 percentage points but remains significant. (The FE results arguably absorb more variation than intended; Appendix Table 1 reveals that some variables have limited variation.) In order to successfully run Lewbel IV models, heteroskedasticity must be present. The Breusch-Pagan test for Lewbel IV models reveals heteroskedasticity to be very present, with a chi-square value of 234.29 and a p-value of approximately zero. Marginal effects for Lewbel IV and propensity score models are strong and significant, showing a 15 percentage point lower probability of being in good health as a result of falling.

Effects for the remaining outcomes generally carry the expected signs; preferred models are the extended, Lewbel IV, and PSM models, which appropriately address endogeneity and yield similar marginal effects. Moreover, the p-value for the difference in coefficients between IV and PSM models shown in Table 3 suggest that there is no significant difference in coefficients for all 
health outcomes. Further statistical tests for differences in coefficients between the LPM (extended) models versus IV and PSM in turn reveal few significant differences in coefficients, suggesting that stepwise estimation has arguably adequately addressed endogeneity, assuming that the IV and PSM models have done so. The overidentification test for IV models suggests that the instrumental variables satisfy the exclusion restriction, with p-values greater than $5 \%$ in all cases except for the health outcome pertaining to psychological problems, which should be interpreted with caution. Results from preferred specifications indicate that falling leads to $0.3517-0.5157$ more difficulties with activities of daily living, a $7.6-12.94$ percentage point increase in heart disease, a $1.92-7.21$ percentage point increase in the probability of having a stroke (although the IV coefficient is insignificant), $0.56-1.0$ point more depression as measured by the CESD scale $(0-8)$, and a 10.14 - 18.57 percentage point increase in the probability of having psychological problems. As expected, little effect is seen for cancer for the IV and PSM specifications. Empirically, we can see that falling is a negative input in the health production function and one that could have adverse long-term effects. Tables 4 and 5 for the effects of number of falls and falling with injury on health outcomes, respectively, confirm these results. ${ }^{20}$ In Table 4, we see that overidentification tests reveal that the instrumental variables employed in IV models are generally not legitimately excludable from the second stage, suggesting that higher-order unobserved variation in the number of falls is correlated with health outcomes. In contrast, these tests suggest that the instrumental variables are valid in all cases when the endogenous variable of interest is falling with an injury, as seen in Table 5. These results reveal that the effect of falling with an injury can be substantial.

The results from hazard models in Table 6 are revealing. They suggest that those who fall are about $70 \%$ more likely to die in the following wave, while those who fall with an injury are

\footnotetext{
${ }^{20}$ Appendix Table 5 shows results where a quadratic term for the number of falls is included to address nonlinearities in the effect of the number of falls on health outcomes. These results reveal that the magnitudes of the effects at the mean are generally larger for the nonlinear models.
} 
approximately $83 \%$ more likely to die in the following wave. Note that the mechanism through which the death occurred and the length of time it took (within the two years) cannot be specified.

Results from additional robustness checks are shown in Appendix Table 3. In the first column, falling is defined using a fall from the previous wave (two years prior). In the second column, falling is defined for individuals who fell more than once; for individuals who fell only one time between waves, the falling variable was assigned a value of zero. Unsurprisingly, these results are stronger in magnitude than those shown in Table 3. In the third column, attrition in the HRS sample is addressed using inverse probability weighting (IPW), in which individuals whose characteristics predict higher attrition rates are given more weight in the regression. These results are consistent with those shown in Table 3.

Results from extended models stratified by gender, marital status, and age group are shown in Appendix Table 4. Perhaps somewhat surprisingly, we do not see striking differences in the magnitudes of the effects between the two categories in the various groups. Stronger effects are found for the "not married" group for activities of daily living, heart disease, depression, and psychological problems, pointing to protective effects of being married. Smaller effects are found for males for heart disease and psychological problems. Only for the three sets of results shown in bold are the differences in coefficients statistically significant at the $5 \%$ level, based on $\chi^{2}$ tests.

\section{Discussion}

While studies have highlighted the costs of fatal and non-fatal falls among older individuals and identified strategies to prevent falls, no prior study has identified the causal effect of falling on morbidity. Given two otherwise identical older individuals, what effect would a fall have on health outcomes - both physical and mental - for one person versus the other? 
Results from this study indicate that falling has substantial causal effects on subsequent health outcomes. Using several different econometric methods to ensure the robustness of the results, falling leads to a decline in the probability of being in good health, and an increase in the probabilities of having heart disease, having a stroke, and having psychological problems. It is associated with lower activities of daily living, and more depression. The magnitudes are meaningful. For example, difficulties with activities of daily living go up by $155 \%$, heart problems go up by $36.5 \%$, and depression goes up by $60 \%$ from the mean as a result of a fall. As a result of a fall with an injury, ADL difficulties go up by $166 \%$, heart problems go up by $46 \%$, and depression goes up by $58 \%$ from the mean values for these health outcomes. ${ }^{21}$

The CDC has recommended exercise, particularly the type that focuses on balance such as Tai Chi (Li et al. 2005; Wolf et al. 1996) as a way to prevent falls, ${ }^{22}$ particularly due to the roles that frailty and sarcopenia (the decline of skeletal muscle tissue with age) play (Landi et al. 2012; Walston 2012). It is suggested that a fear of falling, which is likely to develop after a traumatic fall, should not serve as a deterrent to exercise since the relationship of cardiorespiratory fitness and physical activity with falls is unclear (Mertz et al. 2010; Scheffer et al. 2008; Vellas et al. 1997). Maintaining eyesight, wearing comfortable shoes, installing simple equipment, and making stairs and shower stalls more visible are other simple measures (Hafner 2014a,b), yet much preventive equipment is not covered by Medicare (Pynoos et al. 2005; Day et al. 2002). ${ }^{23}$ Over 95\% of hip fractures are caused by falls (CDC 2015; Hayes et al. 1993), so hip protectors, sewn into undergarments, have also

\footnotetext{
${ }^{21}$ These results are obtained from the average effects from three preferred specifications in Tables 3 and 5: extended models, IV models, and PSM models.

22 See http://www.cdc.gov/homeandrecreationalsafety/falls/adultfalls.html.

${ }^{23}$ The Patient Protection and Affordable Care Act, signed into law in 2010, makes few changes to Medicare, the top five things to know being: (1) Medicare coverage is protected since it is not part of the Health Insurance Marketplace; (2) More preventive services are covered, including a free "wellness" visit, without a charge for the Part B coinsurance or deductible; (3) The donut hole will be closed completely by 2020; (4) New initiatives are in place to support care coordination, so doctors may get additional resources to ensure consistent treatments; (5) The life of the Medicare Trust fund will be extended to at least 2029, a 12-year extension. See https://www.medicare.gov/about-us/affordable-careact/affordable-care-act.html. This information is continually being updated in light of political discussions surrounding health care.
} 
been suggested. ${ }^{24}$ Pynoos et al. (2005) stress that National Health Interview Surveys indicate that the majority of fall injuries among older people occurred inside the house, and measure to help with home modification, which refers to converting or adapting the environment in order to make performing tasks easier, reduce accidents and support independent living, should be made. Figures $4 \mathrm{a}$ and $4 \mathrm{~b}$ highlight how sporadic the home modification programs currently in existence across the various states are. ${ }^{25}$ According to AARP surveys, people prefer to grow old at home (Gross 2007), further highlighting the importance of home modification programs.

Measures are being taken to prevent falls (Gillespie et al. 2012; Moyer 2012; Rose 2005; Stevens 2005). The Fall Prevention Center of Excellence has as its mission to identify best practices in fall prevention and to help communities offer fall prevention programs to older people who are at risk of falling. (Their official website is http://stopfalls.org/.) The National Council on Aging has made preventing falls a priority, such as highlighting the six steps one can take to prevent falls: https://www.ncoa.org/healthy-aging/falls-prevention/. The No More Falls! Study, being conducted by the California State Health Department, integrates fall prevention into an existing community-based public health program for older adults. The Wisconsin Department of Health, in collaboration with the University of Wisconsin, is assessing the effectiveness of a comprehensive approach to preventing falls among high-risk seniors. And the CDC is currently conducting a project to move effective interventions into practice.

There are several limitations to this study. Self-reported falls may be underestimated in a manner unlikely to be random (Cummings et al. 1988). The location of the fall and type of injury

\footnotetext{
${ }^{24}$ Hip fractures were looked into for this study. While information on hip fractures is available in the HRS, information on whether a fall resulted in a hip fracture is unavailable. Including hip fractures on the RHS in regressions predicting falls does not materially alter the results. These results are available upon request.

25 The list of home modification programs appears to be increasing. For example, Maryland, Ohio, and Vermont did not have programs listed in 2015, yet they did in 2016. However, a longer time series for this list does not appear to be available.
} 
that might have resulted from the fall are unavailable. Since panel data are employed, this study does not answer the question of which specific changing demographic characteristics over time may be responsible for the increasing trend in falls, which is a subject of future research. Addressing endogeneity in this context is particularly challenging. Taken together, the empirical results obtained using different estimation strategies in this paper show that falling is a negative input in the health production function and one that could have adverse short- and long-term effects. With the high economic costs associated with falling, investing in simple preventive measures and ensuring that Medicare facilitates this should be key. 


\section{References}

Alexander BH, Rivara FP, Wolf ME. The cost and frequency of hospitalization for fall-related injuries in older adults. American Journal of Public Health 1992;82(7):1020-3.

Belfield, Clive; Kelly, Inas Rashad. The Benefits of Breastfeeding Across the Early Years of Childhood. Journal of Human Capital, 6(3): 251-277, Fall 2012.

Bell AJ, Talbot-Stern JK, Hennessy A. Characteristics and outcomes of older patients presenting to the emergency department after a fall: a retrospective analysis. Medical Journal of Australia 2000;173(4):176-7.

Breusch, Trevor S., and Adrian R. Pagan. 1979. A simple Test for Heteroscedasticity and Random Coefficient Variation. Econometrica 47 (5): 1287-94.

Cameron, KA. The Role of Medication Modification in Fall Prevention. In Falls Free: Promoting a National Falls Prevention Action Plan, National Council on the Aging, 2005: 29-39.

Centers for Disease Control and Prevention, September 21, 2015. Costs of Falls Among Older Adults. National Center for Injury Prevention and Control, Division of Unintentional Injury Prevention. URL: http://www.cdc.gov/homeandrecreationalsafety/falls/fallcost.html. Accessed 8 June 2016.

Clogg, Clifford C.; Petkova, Eva; Haritou, Adamantios. Statistical methods for comparing regression coefficients between models. American Journal of Sociology, Vol 100(5), Mar 1995, 1261 1293. http://dx.doi.org/10.1086/230638

Cummings SR, Nevitt MC, Kidd S. Forgetting falls. The limited accuracy of recall of falls in the elderly. J Am Geriatr Soc 1988;36:613-16.

Dai X, Bumgarner J, Spangler A, Meredith D, Smith SC, Stouffer, GA. Acute ST-Elevation Myocardial Infarction in Patients Hospitalized for Noncardiac Conditions. Journal of the American Heart Association, Apr 4;2(2):e000004. doi: 10.1161/JAHA.113.000004, 2013.

Dave DM, Rashad I, Spasojevic J. The Effects of Retirement on Physical and Mental Health Outcomes. Southern Economic Journal, 75(2): 497-523, October 2008.

Day L, Fildes B, Gordon I, Fitzharris M, Flamer H, Lord S. Randomised factorial trial of falls prevention among older people living in their own homes. BMJ. 325.128 (2002): 7356.

Donald IP, Bulpitt CJ. The prognosis of falls in elderly people living at home. Age and Ageing 1999;28:121-5.

Gawande, A. 2014. Being Mortal: Medicine and What Matters in the End. Metropolitan Books, 1st edition.

Gillespie, LD, Robertson, MC, Gillespie, WH, Sherrington C, Gates S, Clemson LM, Lamb SE. Interventions for preventing falls in older people living in the community. Cochrane Database of Systematic Reviews 2012, Issue 9. Art. No.: CD007146. DOI: 10.1002/14651858.CD007146.pub3. 
Gross, Jane. A Grass-Roots Effort to Grow Old at Home. New York Times, 14 August 2007. URL: http://www.nytimes.com/2007/08/14/health/14aging.html?n=Top $\% 2 F C l a s s i f i e d s \% 2 F R e a$ 1\%20Estate $\% 2$ FLuxury $\% 20$ and $\% 20$ Vacations $\% 2$ FActive $\% 20$ Adult\&_r=2. Accessed 8 June 2016.

Hafner K. Part 1: Bracing for the Falls of an Aging Nation. New York Times November 2, 2014a. URL: http://www.nytimes.com/interactive/2014/11/03/health/bracing-for-the-falls-of-anaging-nation.html.

Hafner K. Part 2: A Tiny Stumble, a Life Upended. New York Times November 3, 2014b. URL: http://www.nytimes.com/2014/11/04/science/a-tiny-stumble-a-life-upended.html.

Hayes WC, Myers ER, Morris JN, et al. Impact near the hip dominates fracture risk in elderly nursing home residents who fall. Calcified Tissue International 1993; 52:192-198.

Jager TE, Weiss HB, Coben JH, Pepe PE. Traumatic brain injuries evaluated in U.S. emergency departments, 1992-1994. Academic Emergency Medicine 2000;7(2):134-40.

Kelly, Inas Rashad, and Sara Markowitz. 2009. Incentives in Obesity and Health Insurance. Inquiry 46 (4): 418-32.

Landi F, Liperoti R, Russo A, Giovannini S, Tosato M, Capoluongo E, Bernabei R, Onder G. Sarcopenia as a risk factor for falls in elderly individuals: results from the ilSIRENTE study. Clin Nutr. 2012 Oct;31(5):652-8. doi: 10.1016/j.clnu.2012.02.007. Epub 2012 Mar 11.

Lawlor DA, Patel R, Ebrahim S. Association between falls in elderly women and chronic diseases and drug use: cross sectional study. BMJ 2003; 327: 712-71.

Leuven E, and B. Sianesi. (2003). PSMATCH2: Stata module to perform full Mahalanobis and propensity score matching, common support graphing, and covariate imbalance testing. URL: http://ideas.repec.org/c/boc/bocode/s432001.html.

Lewbel, Arthur. 2012. Using Heteroscedasticity to Identify and Estimate Mismeasured and Endogenous Regressor Models. J. Bus. and Econ. Statis. 30(1): 67-80.

Li F, Harmer P, Fisher KJ, et al. Tai chi and fall reductions in older adults: a randomized controlled trial. Journal of Gerontology Medical Sciences 2005;60A:187-94.

Lord SR, Smith ST, Menant JC. Vision and falls in older people: risk factors and intervention strategies. Clin Geriatr Med. 2010 Nov;26(4):569-81. doi: 10.1016/j.cger.2010.06.002.

Mahalanobis, Prasanta Chandra (1936). On the generalised distance in statistics. Proceedings of the National Institute of Sciences of India. 2 (1): 49-55.

Mertz KJ, Lee DC, Sui X, Powell KE, Blair SN. Falls among adults: the association of cardiorespiratory fitness and physical activity with walking-related falls. Am J Prev Med. 2010 Jul;39(1):15-24. doi: 10.1016/j.amepre.2010.03.013.

Moyer VA. Prevention of Falls in Community-Dwelling Older Adults: U.S. Preventive Services Task Force Recommendation Statement. Annals of Internal Medicine 2012;157(3):197-204. 
Pynoos J, D Sabata and IH Choi, The Role of the Environment in Fall Prevention at Home and in the Community. In Falls Free: Promoting a National Falls Prevention Action Plan, National Council on the Aging, 2005: 41-54.

Resnick, B. 2013. Hospital Care and the Elderly. Merck Manual Professional Version. October 2013. URL: http://www.merckmanuals.com/professional/geriatrics/provision-of-care-tothe-elderly/hospital-care-and-the-elderly. Accessed 8 June 2016.

Rose, DJ. The Role of Exercise in Reducing Falls and Fall-Related Injuries in Older Adults. In Falls Free: Promoting a National Falls Prevention Action Plan, National Council on the Aging, 2005: 1928.

Rosenbaum, P. R. and Rubin, D.B. (1983). The central role of the propensity score in observational studies for causal effects. Biometrika, 70(1), pp. 41-55.

Sabia, Joseph J. 2007. The Effect of Body Weight on Adolescent Academic Performance. Southern Econ. J. 73 (4): 871-900.

Scheffer AC, Schuurmans MJ, Van Dijk N, Van Der Hoof T. Fear of falling: measurement strategy, prevalence, risk factors and consequences among older persons. Age and Ageing 2008;37:19-24.

Scott V, Peck S. Prevention of Falls and Injuries Among the Elderly. A Special Report from the Office of the Provincial Health Officer, Ministry of Health Planning, British Columbia, January 2004:18-67.

Steinman, Bernard A. Falls and Vision Loss Part 1. 2017. Fall Prevention Center of Excellence. Available at http://www.stopfalls.org/grantees info/files/FallsVision1.pdf.

Sterling DA, O'Connor JA, Bonadies J. Geriatric falls: injury severity is high and disproportionate to mechanism. Journal of Trauma-Injury, Infection and Critical Care 2001;50(1):116-9.

Stevens, JA. Falls Among Older Adults-Risk Factors and Prevention Strategies. In Falls Free: Promoting a National Falls Prevention Action Plan, National Council on the Aging, 2005: 3-18.

Stevens JA. Fatalities and injuries from falls among older adults - United States, 1993-2003 and 2001-2005. MMWR 2006;55.45:1222-24.

Stevens JA, Ballesteros MF, Mack KA, Rudd RA, DeCaro E, Adler G. Gender differences in seeking care for falls in the aged Medicare Population. American Journal of Preventive Medicine 2012;43:59-62.

Stevens JA, Corso PS, Finkelstein EA, Miller TR. The costs of fatal and nonfatal falls among older adults. Injury Prevention 2006;12:290-5.

Stevens JA, Dellinger AM. Motor vehicle and fall related deaths among older Americans 1990-98: sex, race, and ethnic disparities. Injury Prevention 2002;8:272-5.

Stevens JA, Sogolow ED. Gender differences for non-fatal unintentional fall related injuries among older adults. Injury Prevention 2005b;11:115-9. 
Vellas BJ, Wayne SJ, Romero LJ, Baumgartner RN, Garry PJ. Fear of falling and restriction of mobility in elderly fallers. Age and Ageing 1997;26:189-193.

Walston, Jeremy D. Sarcopenia in older adults. Curr Opin Rheumatol. 2012 Nov; 24(6): 623-627. doi: 10.1097/BOR.0b013e328358d59b.

Wolf SL, Barnhart HX, Kutner NG, et al. Reducing frailty and falls in older persons: an investigation of Tai Chi and computerized balance training. Atlanta FICSIT Group. Frailty and Injuries: Cooperative Studies of Intervention Techniques, J Am Geriatr Soc 1996;44:489-97. 
Table 1

Weighted Means for Variables

\begin{tabular}{|c|c|c|c|c|}
\hline Variable & Mean & Std. Dev. & Min & $\operatorname{Max}$ \\
\hline \multicolumn{5}{|l|}{ Falling Vars } \\
\hline Fell since last wave & 0.300 & 0.458 & 0 & 1 \\
\hline Fell more than once since last wave & 0.160 & 0.367 & 0 & 1 \\
\hline Fell in any wave & 0.647 & 0.478 & 0 & 1 \\
\hline Number of falls & 0.857 & 2.845 & 0 & 50 \\
\hline Fall resulted in injury & 0.088 & 0.284 & 0 & 1 \\
\hline \multicolumn{5}{|l|}{ Health Outcomes Vars } \\
\hline Good health & 0.735 & 0.441 & 0 & 1 \\
\hline ADL (Summary Measure) & 0.279 & 0.837 & 0 & 5 \\
\hline Heart & 0.281 & 0.450 & 0 & 1 \\
\hline Stroke & 0.073 & 0.261 & 0 & 1 \\
\hline CESD depression & 1.293 & 1.838 & 0 & 8 \\
\hline Psychological problems & 0.152 & 0.359 & 0 & 1 \\
\hline Cancer & 0.170 & 0.376 & 0 & 1 \\
\hline \multicolumn{5}{|l|}{ Independent Vars } \\
\hline \multicolumn{5}{|l|}{ Biological } \\
\hline Male & 0.449 & 0.497 & 0 & 1 \\
\hline Age & 70.874 & 3.923 & 61 & 81 \\
\hline Number of living parents & 0.101 & 0.315 & 0 & 2 \\
\hline \multicolumn{5}{|l|}{ Socioeconomic } \\
\hline White non-Hispanic & 0.823 & 0.381 & 0 & 1 \\
\hline Black non-Hispanic & 0.101 & 0.301 & 0 & 1 \\
\hline Hispanic & 0.057 & 0.232 & 0 & 1 \\
\hline Other race/ethnicity & 0.019 & 0.135 & 0 & 1 \\
\hline Less than high school & 0.208 & 0.406 & 0 & 1 \\
\hline High school & 0.400 & 0.490 & 0 & 1 \\
\hline Some college & 0.196 & 0.397 & 0 & 1 \\
\hline College & 0.197 & 0.398 & 0 & 1 \\
\hline Single & 0.031 & 0.173 & 0 & 1 \\
\hline Married & 0.674 & 0.469 & 0 & 1 \\
\hline Divorced & 0.106 & 0.308 & 0 & 1 \\
\hline Widowed & 0.189 & 0.391 & 0 & 1 \\
\hline Income (in thousands) & 57.883 & 377.443 & 0 & 60,014 \\
\hline Number of children & 3.065 & 1.928 & 0 & 35 \\
\hline Veteran status & 0.266 & 0.442 & 0 & 1 \\
\hline \multicolumn{5}{|l|}{ Behavioral } \\
\hline Prescription drug use & 0.860 & 0.347 & 0 & 1 \\
\hline Obese & 0.302 & 0.459 & 0 & 1 \\
\hline
\end{tabular}




\begin{tabular}{lrrrr} 
Ever drinks any alcohol & 0.498 & 0.500 & 0 & 1 \\
Smoke & 0.115 & 0.319 & 0 & 1 \\
\hline Medical & & & & \\
\hline Arthritis & 0.666 & 0.472 & 0 & 1 \\
Doctor use since last wave & 0.946 & 0.226 & 0 & 1 \\
\hline Additional Vars & & & & \\
\hline Year of survey & 2006.247 & 4.045 & 1998 & 2012 \\
Birth year & 1935.374 & 3.053 & 1931 & 1941 \\
Census division & 4.897 & 2.360 & 1 & 9 \\
Baseline excellent or very good health (1992) & 0.576 & 0.494 & 0 & 1 \\
Died & 0.007 & 0.082 & 0 & 1 \\
Year of death (if applicable) & 2008.242 & 3.092 & 1998 & 2013 \\
\hline
\end{tabular}

Notes: Weighted means are based on data from the Health and Retirement Study, 1998-2012. Number of person-year observations is 35,319 . 
Table 2: Estimating the Probability of Falling

\begin{tabular}{|c|c|c|c|c|c|c|}
\hline \multirow[b]{2}{*}{ VARIABLES } & \multicolumn{3}{|c|}{ Fall } & \multicolumn{3}{|c|}{ Fall resulted in injury } \\
\hline & Limited & Extended & FE & Limited & Extended & FE \\
\hline Male & $\begin{array}{c}-0.0468^{* * *} \\
(0.007)\end{array}$ & $\begin{array}{c}-0.0027 \\
(0.010)\end{array}$ & & $\begin{array}{c}-0.0466^{* * *} \\
(0.004)\end{array}$ & $\begin{array}{c}-0.0319 * * * \\
(0.005)\end{array}$ & \\
\hline Age & $\begin{array}{c}0.0066^{* * *} \\
(0.001)\end{array}$ & $\begin{array}{c}0.0055^{* * *} \\
(0.001)\end{array}$ & $\begin{array}{c}0.0153^{* * *} \\
(0.001)\end{array}$ & $\begin{array}{c}0.0025^{* * *} \\
(0.001)\end{array}$ & $\begin{array}{c}0.0020^{* * *} \\
(0.001)\end{array}$ & $\begin{array}{c}0.0047 * * * \\
(0.000)\end{array}$ \\
\hline Number of living parents & $\begin{array}{c}-0.0245^{* *} \\
(0.011)\end{array}$ & $\begin{array}{l}-0.0153 \\
(0.011)\end{array}$ & $\begin{array}{l}0.0031 \\
(0.012)\end{array}$ & $\begin{array}{c}-0.0099 * \\
(0.006)\end{array}$ & $\begin{array}{l}-0.0051 \\
(0.006)\end{array}$ & $\begin{array}{l}0.0088 \\
(0.008)\end{array}$ \\
\hline Black non-Hispanic & & $\begin{array}{c}-0.0546^{* * *} \\
(0.010)\end{array}$ & & & $\begin{array}{c}-0.0279 * * * \\
(0.005)\end{array}$ & \\
\hline Hispanic & & $\begin{array}{l}-0.0122 \\
(0.014)\end{array}$ & & & $\begin{array}{l}0.0109 \\
(0.007)\end{array}$ & \\
\hline Other race/ethnicity & & $\begin{array}{r}-0.0141 \\
(0.027)\end{array}$ & & & $\begin{array}{l}0.0194 \\
(0.016)\end{array}$ & \\
\hline High school & & $\begin{array}{c}-0.0182 * \\
(0.010)\end{array}$ & & & $\begin{array}{l}-0.0053 \\
(0.005)\end{array}$ & \\
\hline Some college & & $\begin{array}{l}0.0097 \\
(0.012)\end{array}$ & & & $\begin{array}{l}0.0040 \\
(0.006)\end{array}$ & \\
\hline College & & $\begin{array}{l}-0.0079 \\
(0.012)\end{array}$ & & & $\begin{array}{l}0.0049 \\
(0.007)\end{array}$ & \\
\hline Married or partnered & & $\begin{array}{c}-0.0116 \\
(0.020)\end{array}$ & $\begin{array}{l}0.0528 \\
(0.051)\end{array}$ & & $\begin{array}{l}0.0085 \\
(0.010)\end{array}$ & $\begin{array}{l}-0.0018 \\
(0.033)\end{array}$ \\
\hline Divorced or separated & & $\begin{array}{l}0.0344 \\
(0.022)\end{array}$ & $\begin{array}{l}0.0700 \\
(0.052)\end{array}$ & & $\begin{array}{c}0.0308^{* *} \\
(0.014)\end{array}$ & $\begin{array}{l}0.0146 \\
(0.035)\end{array}$ \\
\hline Widowed & & $\begin{array}{c}0.0394 * \\
(0.021)\end{array}$ & $\begin{array}{l}0.0624 \\
(0.050)\end{array}$ & & $\begin{array}{l}0.0220^{*} \\
(0.012)\end{array}$ & $\begin{array}{l}0.0074 \\
(0.033)\end{array}$ \\
\hline Income & & $\begin{array}{c}-0.0001 \\
(0.00003)\end{array}$ & $\begin{array}{l}-0.00004 \\
(0.00005)\end{array}$ & & $\begin{array}{l}-0.00002 \\
(0.00003)\end{array}$ & $\begin{array}{l}-0.00001 \\
(0.00004)\end{array}$ \\
\hline Income squared & & $\begin{array}{c}6.50 \mathrm{e}-10 \\
(5.57 \mathrm{e}-10)\end{array}$ & $\begin{array}{c}3.81 \mathrm{e}-10 \\
(1.27 \mathrm{e}-08)\end{array}$ & & $\begin{array}{c}3.09 e-10 \\
(4.23 e-10)\end{array}$ & $\begin{array}{r}1.75 e-10 \\
(9.73 e-09)\end{array}$ \\
\hline Number of children & & $\begin{array}{l}0.0006 \\
(0.002)\end{array}$ & & & $\begin{array}{l}0.0001 \\
(0.001)\end{array}$ & \\
\hline Veteran status & & $\begin{array}{c}-0.0183^{*} \\
(0.011)\end{array}$ & & & $\begin{array}{l}-0.0055 \\
(0.006)\end{array}$ & \\
\hline Prescription drugs & & $\begin{array}{c}0.0762^{* * *} \\
(0.009)\end{array}$ & $\begin{array}{l}0.0137 \\
(0.009)\end{array}$ & & $\begin{array}{c}0.0348^{* * *} \\
(0.004)\end{array}$ & $\begin{array}{c}0.0118^{*} \\
(0.007)\end{array}$ \\
\hline Obese & & $\begin{array}{c}0.0401^{* * *} \\
(0.007)\end{array}$ & $\begin{array}{c}-0.0355^{* * *} \\
(0.010)\end{array}$ & & $\begin{array}{l}0.0024 \\
(0.004)\end{array}$ & $\begin{array}{c}-0.0030 \\
(0.007)\end{array}$ \\
\hline Alcohol (ever drink) & & $-0.0337 * * *$ & 0.0043 & & $-0.0199 * * *$ & $-0.0112 * *$ \\
\hline
\end{tabular}




\begin{tabular}{|c|c|c|c|c|c|c|}
\hline \multirow{3}{*}{ Smokes now } & & $(0.007)$ & $(0.007)$ & & $(0.003)$ & $(0.005)$ \\
\hline & & 0.0036 & -0.0134 & & -0.0042 & -0.0065 \\
\hline & & $(0.011)$ & $(0.018)$ & & $(0.005)$ & $(0.010)$ \\
\hline \multirow[t]{2}{*}{ Arthritis } & & $0.0947 * * *$ & 0.0076 & & $0.0251^{* * *}$ & 0.0071 \\
\hline & & $(0.007)$ & $(0.010)$ & & $(0.004)$ & $(0.006)$ \\
\hline \multirow[t]{2}{*}{ Visited doctor } & & $0.0420^{* * *}$ & $0.0227 *$ & & $0.0437 * * *$ & $0.0254^{* * *}$ \\
\hline & & $(0.012)$ & $(0.012)$ & & $(0.005)$ & $(0.007)$ \\
\hline Person-year observations & 35,319 & 35,319 & 35,319 & 35,319 & 35,319 & 35,319 \\
\hline Number of individuals & & & 7,351 & & & 7,351 \\
\hline
\end{tabular}

Notes: Analysis based on 1998-2012 HRS data. Marginal effects of probit models are reported. All models include controls for Census division and year of survey. Standard errors account for clustering by person id. *** p-value $\leq 0.01 ; * * 0.01<$ p-value $\leq 0.05 ; * 0.05<$ p-value $\leq 0.10$. 
Table 3: Effect of Falling on Health Outcomes

\begin{tabular}{|c|c|c|c|c|c|c|c|}
\hline & Limited & Extended & $\mathrm{FE}$ & Lewbel IV & $\begin{array}{c}\text { Propensity } \\
\text { Score }\end{array}$ & $\begin{array}{l}\text { IV vs PSM } \\
\text { (p-value) }\end{array}$ & $\begin{array}{c}\text { Lewbel IV } \\
\text { FE }\end{array}$ \\
\hline Good health & $\begin{array}{c}-0.1719 * * * \\
(0.007)\end{array}$ & $\begin{array}{c}-0.1390 * * * \\
(0.006)\end{array}$ & $\begin{array}{c}-0.0392^{* * *} \\
(0.005)\end{array}$ & $\begin{array}{c}-0.1534 * * * \\
(0.051)\end{array}$ & $\begin{array}{c}-0.1532^{* * *} \\
(0.041)\end{array}$ & 0.997 & $\begin{array}{c}-0.1197 * * * \\
(0.029)\end{array}$ \\
\hline $\begin{array}{l}\text { Observations } \\
\text { Number of individuals } \\
\text { F-stat } \\
\text { Sargan pval }\end{array}$ & 35,290 & 35,290 & $\begin{array}{c}35,290 \\
7,350\end{array}$ & $\begin{array}{l}50.32 \\
0.310\end{array}$ & 35,290 & & $\begin{array}{c}34,830 \\
6,890 \\
78.10 \\
0.0107\end{array}$ \\
\hline ADL Sum & $\begin{array}{c}0.3923 * * * \\
(0.016)\end{array}$ & $\begin{array}{c}0.3517^{* * *} \\
(0.015)\end{array}$ & $\begin{array}{c}0.1189 * * * \\
(0.009)\end{array}$ & $\begin{array}{c}0.5157^{* * *} \\
(0.124)\end{array}$ & $\begin{array}{c}0.3590 * * * \\
(0.054)\end{array}$ & 0.246 & $\begin{array}{c}0.7204 * * * \\
(0.059)\end{array}$ \\
\hline $\begin{array}{l}\text { Observations } \\
\text { Number of individuals } \\
\text { F-stat } \\
\text { Sargan pval }\end{array}$ & 35,318 & 35,318 & $\begin{array}{c}35,318 \\
7,350\end{array}$ & $\begin{array}{r}35,318 \\
50.77 \\
0.0665\end{array}$ & 35,318 & & $\begin{array}{c}34,861 \\
6,893 \\
78.38 \\
0\end{array}$ \\
\hline Heart disease & $\begin{array}{c}0.1024 * * * \\
(0.008)\end{array}$ & $\begin{array}{c}0.0760 * * * \\
(0.007)\end{array}$ & $\begin{array}{c}0.0105^{* * *} \\
(0.003)\end{array}$ & $\begin{array}{c}0.1037 * * \\
(0.051)\end{array}$ & $\begin{array}{c}0.1294 * * * \\
(0.041)\end{array}$ & 0.692 & $\begin{array}{c}0.0796^{* * *} \\
(0.021)\end{array}$ \\
\hline $\begin{array}{l}\text { Observations } \\
\text { Number of individuals } \\
\text { F-stat } \\
\text { Sargan pval }\end{array}$ & 35,273 & 35,273 & $\begin{array}{c}35,273 \\
7,349\end{array}$ & $\begin{array}{l}51.78 \\
0.196\end{array}$ & 35,273 & & $\begin{array}{l}34,813 \\
6,889 \\
78.96 \\
0.663\end{array}$ \\
\hline Stroke & $\begin{array}{c}0.0622^{* * *} \\
(0.005)\end{array}$ & $\begin{array}{c}0.0559 * * * \\
(0.005)\end{array}$ & $\begin{array}{c}0.0176^{* * *} \\
(0.002)\end{array}$ & $\begin{array}{l}0.0192 \\
(0.033)\end{array}$ & $\begin{array}{c}0.0721 * * * \\
(0.020)\end{array}$ & 0.171 & $\begin{array}{c}0.0651 * * * \\
(0.014)\end{array}$ \\
\hline $\begin{array}{l}\text { Observations } \\
\text { Number of individuals } \\
\text { F-stat } \\
\text { Sargan pval }\end{array}$ & 35,305 & 35,305 & $\begin{array}{c}35,305 \\
7,350\end{array}$ & $\begin{array}{l}35,305 \\
50.90 \\
0.441\end{array}$ & 35,305 & & $\begin{array}{c}34,847 \\
6,892 \\
78.36 \\
0.000341\end{array}$ \\
\hline Depression (CESD) & $\begin{array}{c}0.6626^{* * *} \\
(0.032)\end{array}$ & $\begin{array}{c}0.5597 * * * \\
(0.029)\end{array}$ & $\begin{array}{c}0.1267 * * * \\
(0.020)\end{array}$ & $\begin{array}{c}0.9980 * * * \\
(0.197)\end{array}$ & $\begin{array}{c}0.5990 * * * \\
(0.150)\end{array}$ & 0.107 & $\begin{array}{c}0.3142^{* * *} \\
(0.105)\end{array}$ \\
\hline $\begin{array}{l}\text { Observations } \\
\text { Number of individuals } \\
\text { F-stat }\end{array}$ & 33,223 & 33,223 & $\begin{array}{c}33,223 \\
7,082\end{array}$ & 68.03 & 33,223 & & $\begin{array}{l}32,676 \\
6,535 \\
99.40\end{array}$ \\
\hline
\end{tabular}




\begin{tabular}{|c|c|c|c|c|c|c|c|}
\hline Sargan pval & & & & 0.197 & & & 0.468 \\
\hline $\begin{array}{l}\text { Psychological } \\
\text { problems }\end{array}$ & $\begin{array}{c}0.1220^{* * *} \\
(0.007)\end{array}$ & $\begin{array}{c}0.1014 * * * \\
(0.006)\end{array}$ & $\begin{array}{c}0.0202^{* * *} \\
(0.003)\end{array}$ & $\begin{array}{c}0.1857^{* * *} \\
(0.044)\end{array}$ & $\begin{array}{c}0.1357 * * * \\
(0.027)\end{array}$ & 0.331 & $\begin{array}{c}0.0728^{* * *} \\
(0.017)\end{array}$ \\
\hline $\begin{array}{l}\text { Observations } \\
\text { Number of individuals } \\
\text { F-stat } \\
\text { Sargan pval }\end{array}$ & 35,264 & 35,264 & $\begin{array}{c}35,264 \\
7,350\end{array}$ & $\begin{array}{c}35,264 \\
51.58 \\
0.000247\end{array}$ & 35,264 & & $\begin{array}{l}34,803 \\
6,889 \\
79.11 \\
0.593\end{array}$ \\
\hline Cancer & $\begin{array}{c}0.0205^{* * *} \\
(0.006)\end{array}$ & $\begin{array}{c}0.0155^{* *} \\
(0.006)\end{array}$ & $\begin{array}{l}0.0047 * \\
(0.003)\end{array}$ & $\begin{array}{l}0.0174 \\
(0.040)\end{array}$ & $\begin{array}{l}0.0491 \\
(0.032)\end{array}$ & 0.537 & $\begin{array}{c}-0.0351 * * \\
(0.017)\end{array}$ \\
\hline $\begin{array}{l}\text { Observations } \\
\text { Number of individuals } \\
\text { F-stat } \\
\text { Sargan pval }\end{array}$ & 35,295 & 35,295 & $\begin{array}{c}35,295 \\
7,350\end{array}$ & $\begin{array}{l}51.50 \\
0.571\end{array}$ & 35,295 & & $\begin{array}{r}34,837 \\
6,892 \\
79.08 \\
0.0378\end{array}$ \\
\hline
\end{tabular}

Notes: Analysis based on 1998-2012 HRS data. Limited models include controls for gender, age, and number of living parents. Extended models include controls for gender, age, number of living parents, race/ethnic status, education, marital status, income, number of children, veteran status, use of prescription drugs, obesity, alcohol consumption, smoking status, arthritis, physician use, year of survey, and Census division. Standard errors account for clustering by person id. *** p-value $\leq$ $0.01 ; * * 0.01<\mathrm{p}$-value $\leq 0.05 ; * 0.05<\mathrm{p}$-value $\leq 0.10$. Fixed effects IV models have a slightly lower number of observations due to the presence of singleton groups. 
Table 4: Effect of Number of Falls on Health Outcomes

\begin{tabular}{|c|c|c|c|c|c|c|c|}
\hline & Limited & Extended & $\mathrm{FE}$ & Lewbel IV & $\begin{array}{l}\text { Propensity } \\
\text { Score }\end{array}$ & $\begin{array}{c}\text { IV vs PSM } \\
\text { (p-value) }\end{array}$ & $\begin{array}{c}\text { Lewbel IV } \\
\text { FE }\end{array}$ \\
\hline Good health & $\begin{array}{c}-0.0243^{* * *} \\
(0.002)\end{array}$ & $\begin{array}{c}-0.0204 * * * \\
(0.001)\end{array}$ & $\begin{array}{c}-0.0061 * * * \\
(0.001)\end{array}$ & $\begin{array}{c}-0.0093 * * * \\
(0.002)\end{array}$ & $\begin{array}{c}-0.0709 * * \\
(0.033)\end{array}$ & 0.067 & $\begin{array}{c}-0.0036 * * \\
(0.001)\end{array}$ \\
\hline $\begin{array}{l}\text { Observations } \\
\text { Number of individuals } \\
\text { F-stat } \\
\text { Sargan pval }\end{array}$ & 35,290 & 35,290 & $\begin{array}{c}35,290 \\
7,350\end{array}$ & $\begin{array}{c}1313 \\
0.0300\end{array}$ & 35,290 & & $\begin{array}{c}34,830 \\
6,890 \\
1272 \\
0.000313\end{array}$ \\
\hline ADL Sum & $\begin{array}{c}0.0666^{* * *} \\
(0.005)\end{array}$ & $\begin{array}{c}0.0619 \text { *** } \\
(0.005)\end{array}$ & $\begin{array}{c}0.0269 * * * \\
(0.002)\end{array}$ & $\begin{array}{c}0.0342^{* * *} \\
(0.007)\end{array}$ & $\begin{array}{c}0.1021 * \\
(0.053)\end{array}$ & 0.205 & $\begin{array}{c}0.0374 * * * \\
(0.003)\end{array}$ \\
\hline $\begin{array}{l}\text { Observations } \\
\text { Number of individuals } \\
\text { F-stat } \\
\text { Sargan pval }\end{array}$ & 35,318 & 35,318 & $\begin{array}{c}35,318 \\
7,350\end{array}$ & $\begin{array}{c}1320 \\
0.0199\end{array}$ & 35,318 & & $\begin{array}{c}34,861 \\
6,893 \\
1270 \\
0\end{array}$ \\
\hline Heart disease & $\begin{array}{c}0.0126^{* * *} \\
(0.002)\end{array}$ & $\begin{array}{c}0.0094 * * * \\
(0.001)\end{array}$ & $\begin{array}{c}0.0025^{* * *} \\
(0.001)\end{array}$ & $\begin{array}{l}0.0031 \\
(0.002)\end{array}$ & $\begin{array}{c}0.0791 * * \\
(0.035)\end{array}$ & 0.029 & $\begin{array}{l}0.0013 \\
(0.001)\end{array}$ \\
\hline $\begin{array}{l}\text { Observations } \\
\text { Number of individuals } \\
\text { F-stat } \\
\text { Sargan pval }\end{array}$ & 35,273 & 35,273 & $\begin{array}{c}35,273 \\
7,349\end{array}$ & $\begin{array}{c}35,273 \\
1348 \\
0.00112\end{array}$ & 35,273 & & $\begin{array}{c}34,813 \\
6,889 \\
1287 \\
0.186\end{array}$ \\
\hline Stroke & $\begin{array}{c}0.0110^{* * *} \\
(0.001)\end{array}$ & $\begin{array}{c}0.0101 * * * \\
(0.001)\end{array}$ & $\begin{array}{c}0.0029 * * * \\
(0.000)\end{array}$ & $\begin{array}{c}0.0065^{* * *} \\
(0.002)\end{array}$ & $\begin{array}{c}0.0398^{* *} \\
(0.019)\end{array}$ & 0.084 & $\begin{array}{c}0.0039 * * * \\
(0.001)\end{array}$ \\
\hline $\begin{array}{l}\text { Observations } \\
\text { Number of individuals } \\
\text { F-stat } \\
\text { Sargan pval }\end{array}$ & 35,305 & 35,305 & $\begin{array}{c}35,305 \\
7,350\end{array}$ & $\begin{array}{l}1319 \\
0.721\end{array}$ & 35,305 & & $\begin{array}{c}34,847 \\
6,892 \\
1270 \\
0.00679\end{array}$ \\
\hline Depression (CESD) & $\begin{array}{c}0.0987 * * * \\
(0.009)\end{array}$ & $\begin{array}{c}0.0857 * * * \\
(0.007)\end{array}$ & $\begin{array}{c}0.0260^{* * * *} \\
(0.004)\end{array}$ & $\begin{array}{c}0.0465^{* * *} \\
(0.011)\end{array}$ & $\begin{array}{c}0.3144^{* *} \\
(0.134)\end{array}$ & 0.046 & $\begin{array}{c}0.0180^{* * *} \\
(0.007)\end{array}$ \\
\hline $\begin{array}{l}\text { Observations } \\
\text { Number of individuals } \\
\text { F-stat }\end{array}$ & 33,223 & 33,223 & $\begin{array}{c}33,223 \\
7,082\end{array}$ & 1269 & 33,223 & & $\begin{array}{l}32,676 \\
6,535 \\
1043\end{array}$ \\
\hline
\end{tabular}




\begin{tabular}{|c|c|c|c|c|c|c|c|}
\hline Sargan pval & & & & $2.11 \mathrm{e}-05$ & & & 0.0193 \\
\hline $\begin{array}{l}\text { Psychological } \\
\text { problems }\end{array}$ & $\begin{array}{c}0.0184 * * * \\
(0.001)\end{array}$ & $\begin{array}{c}0.0157^{* * *} \\
(0.001)\end{array}$ & $\begin{array}{c}0.0039 * * * \\
(0.000)\end{array}$ & $\begin{array}{c}0.0062^{* * *} \\
(0.002)\end{array}$ & $\begin{array}{c}0.0679 * * * \\
(0.023)\end{array}$ & 0.008 & $\begin{array}{c}0.0025^{* * *} \\
(0.001)\end{array}$ \\
\hline $\begin{array}{l}\text { Observations } \\
\text { Number of individuals } \\
\text { F-stat } \\
\text { Sargan pval }\end{array}$ & 35,264 & 35,264 & $\begin{array}{c}35,264 \\
7,350\end{array}$ & $\begin{array}{c}35,264 \\
1327 \\
0.000711\end{array}$ & 35,264 & & $\begin{array}{c}34,803 \\
6,889 \\
1265 \\
0.000183\end{array}$ \\
\hline Cancer & $\begin{array}{c}0.0037 * * * \\
(0.001)\end{array}$ & $\begin{array}{c}0.0031^{* * *} \\
(0.001)\end{array}$ & $\begin{array}{l}0.0004 \\
(0.000)\end{array}$ & $\begin{array}{l}0.0007 \\
(0.002)\end{array}$ & $\begin{array}{l}0.0296 \\
(0.031)\end{array}$ & 0.354 & $\begin{array}{l}-0.0004 \\
(0.001)\end{array}$ \\
\hline $\begin{array}{l}\text { Observations } \\
\text { Number of individuals } \\
\text { F-stat } \\
\text { Sargan pval }\end{array}$ & 35,295 & 35,295 & $\begin{array}{c}35,295 \\
7,350\end{array}$ & $\begin{array}{l}1319 \\
0.464\end{array}$ & 35,295 & & $\begin{array}{l}34,837 \\
6,892 \\
1268 \\
0.964\end{array}$ \\
\hline
\end{tabular}

Notes: Analysis based on 1998-2012 HRS data. Limited models include controls for gender, age, and number of living parents. Extended models include controls for gender, age, number of living parents, race/ethnic status, education, marital status, income, number of children, veteran status, use of prescription drugs, obesity, alcohol consumption, smoking status, arthritis, physician use, year of survey, and Census division. Standard errors account for clustering by person id. *** $\mathrm{p}$-value $\leq$ $0.01 ; * * 0.01<\mathrm{p}$-value $\leq 0.05 ; * 0.05<\mathrm{p}$-value $\leq 0.10$. Fixed effects IV models have a slightly lower number of observations due to the presence of singleton groups. 
Table 5: Effect of Falling with Injury on Health Outcomes

\begin{tabular}{|c|c|c|c|c|c|c|c|}
\hline & Limited & Extended & $\mathrm{FE}$ & Lewbel IV & $\begin{array}{c}\text { Propensity } \\
\text { Score }\end{array}$ & $\begin{array}{c}\text { IV vs PSM } \\
\text { (p-value) }\end{array}$ & $\begin{array}{c}\text { Lewbel IV } \\
\text { FE }\end{array}$ \\
\hline Good health & $\begin{array}{c}-0.1641 * * * \\
(0.011)\end{array}$ & $\begin{array}{c}-0.1312^{* * *} \\
(0.010)\end{array}$ & $\begin{array}{c}-0.0300 * * * \\
(0.007)\end{array}$ & $\begin{array}{c}-0.7072^{* * *} \\
(0.159)\end{array}$ & $\begin{array}{c}-0.1505^{* * *} \\
(0.034)\end{array}$ & 0.001 & $\begin{array}{c}-0.3397 * * * \\
(0.108)\end{array}$ \\
\hline $\begin{array}{l}\text { Observations } \\
\text { Number of individuals } \\
\text { F-stat } \\
\text { Sargan pval }\end{array}$ & 35,290 & 35,290 & $\begin{array}{c}35,290 \\
7,350\end{array}$ & $\begin{array}{l}17.93 \\
0.280\end{array}$ & 35,290 & & $\begin{array}{c}34,830 \\
6,890 \\
12.50 \\
0.00290\end{array}$ \\
\hline ADL Sum & $\begin{array}{c}0.4687^{* * *} \\
(0.031)\end{array}$ & $\begin{array}{c}0.4279 * * * \\
(0.029)\end{array}$ & $\begin{array}{c}0.1621 * * * \\
(0.013)\end{array}$ & $\begin{array}{c}0.5002^{* * *} \\
(0.104)\end{array}$ & $\begin{array}{c}0.4584 * * * \\
(0.067)\end{array}$ & 0.736 & $\begin{array}{c}0.4264 * * * \\
(0.042)\end{array}$ \\
\hline $\begin{array}{l}\text { Observations } \\
\text { Number of individuals } \\
\text { F-stat } \\
\text { Sargan pval }\end{array}$ & 35,318 & 35,318 & $\begin{array}{c}35,318 \\
7,350\end{array}$ & $\begin{array}{l}35,318 \\
351.7 \\
0.432\end{array}$ & 35,318 & & $\begin{array}{c}34,861 \\
6,893 \\
319.7 \\
0\end{array}$ \\
\hline Heart disease & $\begin{array}{c}0.1170^{* * *} \\
(0.011)\end{array}$ & $\begin{array}{c}0.0884 * * * \\
(0.011)\end{array}$ & $\begin{array}{l}0.0050 \\
(0.005)\end{array}$ & $\begin{array}{c}0.1691 * * * \\
(0.036)\end{array}$ & $\begin{array}{c}0.1432 * * * \\
(0.047)\end{array}$ & 0.661 & $\begin{array}{l}0.0116 \\
(0.016)\end{array}$ \\
\hline $\begin{array}{l}\text { Observations } \\
\text { Number of individuals } \\
\text { F-stat } \\
\text { Sargan pval }\end{array}$ & 35,273 & 35,273 & $\begin{array}{c}35,273 \\
7,349\end{array}$ & $\begin{array}{l}35,273 \\
352.1 \\
0.579\end{array}$ & 35,273 & & $\begin{array}{c}34,813 \\
6,889 \\
318.6 \\
0.198\end{array}$ \\
\hline Stroke & $\begin{array}{c}0.0592^{* * *} \\
(0.007)\end{array}$ & $\begin{array}{c}0.0518^{* * *} \\
(0.007)\end{array}$ & $\begin{array}{c}0.0068^{* *} \\
(0.003)\end{array}$ & $\begin{array}{l}0.0172 \\
(0.025)\end{array}$ & $\begin{array}{c}0.0717^{* * *} \\
(0.027)\end{array}$ & 0.142 & $\begin{array}{l}0.0140 \\
(0.011)\end{array}$ \\
\hline $\begin{array}{l}\text { Observations } \\
\text { Number of individuals } \\
\text { F-stat } \\
\text { Sargan pval }\end{array}$ & 35,305 & 35,305 & $\begin{array}{c}35,305 \\
7,350\end{array}$ & $\begin{array}{l}35,305 \\
350.9 \\
0.218\end{array}$ & 35,305 & & $\begin{array}{c}34,847 \\
6,892 \\
319.8 \\
0.000216\end{array}$ \\
\hline Depression (CESD) & $\begin{array}{c}0.7320^{* * *} \\
(0.054)\end{array}$ & $\begin{array}{c}0.6429^{* * *} \\
(0.050)\end{array}$ & $\begin{array}{c}0.1595^{* * *} \\
(0.030)\end{array}$ & $\begin{array}{c}0.8544^{* * *} \\
(0.148)\end{array}$ & $\begin{array}{c}0.7352^{* * *} \\
(0.133)\end{array}$ & 0.549 & $\begin{array}{c}0.2563^{* * *} \\
(0.084)\end{array}$ \\
\hline $\begin{array}{l}\text { Observations } \\
\text { Number of individuals } \\
\text { F-stat }\end{array}$ & 33,223 & 33,223 & $\begin{array}{c}33,223 \\
7,082\end{array}$ & 33,223 & 33,223 & & $\begin{array}{l}32,676 \\
6,535 \\
381.1\end{array}$ \\
\hline
\end{tabular}




\begin{tabular}{|c|c|c|c|c|c|c|c|}
\hline Sargan pval & & & & 0.737 & & & 0.0649 \\
\hline $\begin{array}{l}\text { Psychological } \\
\text { problems }\end{array}$ & $\begin{array}{c}0.1382^{* * *} \\
(0.010)\end{array}$ & $\begin{array}{c}0.1170 * * * \\
(0.010)\end{array}$ & $\begin{array}{c}0.0111 * * * \\
(0.004)\end{array}$ & $\begin{array}{c}0.2291 * * * \\
(0.033)\end{array}$ & $\begin{array}{c}0.1640 * * * \\
(0.028)\end{array}$ & 0.132 & $\begin{array}{c}0.0468^{* * *} \\
(0.013)\end{array}$ \\
\hline $\begin{array}{l}\text { Observations } \\
\text { Number of individuals } \\
\text { F-stat } \\
\text { Sargan pval }\end{array}$ & 35,264 & 35,264 & $\begin{array}{c}35,264 \\
7,350\end{array}$ & $\begin{array}{l}351.4 \\
0.758\end{array}$ & 35,264 & & $\begin{array}{l}34,803 \\
6,889 \\
320.5 \\
0.327\end{array}$ \\
\hline Cancer & $\begin{array}{l}0.0165^{*} \\
(0.009)\end{array}$ & $\begin{array}{l}0.0108 \\
(0.008)\end{array}$ & $\begin{array}{l}-0.0023 \\
(0.004)\end{array}$ & $\begin{array}{l}0.0097 \\
(0.027)\end{array}$ & $\begin{array}{l}0.0469 \\
(0.037)\end{array}$ & 0.413 & $\begin{array}{l}-0.0163 \\
(0.013)\end{array}$ \\
\hline $\begin{array}{l}\text { Observations } \\
\text { Number of individuals } \\
\text { F-stat } \\
\text { Sargan pval }\end{array}$ & 35,295 & 35,295 & $\begin{array}{c}35,295 \\
7,350\end{array}$ & $\begin{array}{l}357.1 \\
0.789\end{array}$ & 35,295 & & $\begin{array}{l}34,837 \\
6,892 \\
324.3 \\
0.211\end{array}$ \\
\hline
\end{tabular}

Notes: Analysis based on 1998-2012 HRS data. Limited models include controls for gender, age, and number of living parents. Extended models include controls for gender, age, number of living parents, race/ethnic status, education, marital status, income, number of children, veteran status, use of prescription drugs, obesity, alcohol consumption, smoking status, arthritis, physician use, year of survey, and Census division. Standard errors account for clustering by person id. *** p-value $\leq$ $0.01 ; * * 0.01<\mathrm{p}$-value $\leq 0.05 ; * 0.05<\mathrm{p}$-value $\leq 0.10$. Fixed effects IV models have a slightly lower number of observations due to the presence of singleton groups. 
Table 6

Hazard Models: Probability of Death

\begin{tabular}{lccc}
\hline & Cox Proportional Hazard & Exponential & Weibull \\
\hline Any fall & $1.7050^{* * *}$ & $1.7128^{* * *}$ & $1.6938^{* * *}$ \\
& $(0.223)$ & $(0.223)$ & $(0.221)$ \\
\hline No. of falls & $1.0339^{* *}$ & & $1.0303^{* *}$ \\
& $(0.014)$ & $1.0312^{* *}$ & $(0.014)$ \\
& & $(0.014)$ & \\
\hline Fall w/ injury & $1.8224^{* * *}$ & & $1.8254^{* * *}$ \\
& $(0.332)$ & $1.8360^{* * *}$ & $(0.333)$ \\
\hline Person-year & & $(0.335)$ & 35,319 \\
Observations & 35,319 & & \\
\hline
\end{tabular}

Notes: Analysis based on 1998-2012 HRS data. Hazard ratios are reported. Each cell represents a separate regression. All models include controls for gender, race/ethnic status, education, number of children, marital status, income, number of living parents, veteran status, and Census division. $* * *$ p-value $\leq 0.01 ; * * 0.01<$ p-value $\leq 0.05 ; * 0.05<$ p-value $\leq 0.10$. 
Appendix Table 1: Within Percent and Transition Probabilities for Select Variables

\begin{tabular}{|c|c|c|c|c|c|}
\hline Variable & $\begin{array}{l}\text { Within } \\
\text { Percent }\end{array}$ & $P(0 \mid 0)$ & $P(1 \mid 0)$ & $\mathbf{P}(0 \mid 1)$ & $\mathbf{P}(1 \mid 1)$ \\
\hline \multicolumn{6}{|l|}{ Falling Vars } \\
\hline Fell since last wave & 64.01 & 78.46 & 21.54 & 44.79 & 55.21 \\
\hline Fell more than once since last wave & 73.61 & 88.78 & 11.22 & 49.89 & 50.11 \\
\hline Number of falls & 50.31 & - & - & - & - \\
\hline Fall resulted in injury & 78.26 & 92.68 & 7.32 & 71.64 & 28.36 \\
\hline \multicolumn{6}{|l|}{ Health Outcomes Vars } \\
\hline Good health & 73.82 & 73.40 & 26.60 & 13.07 & 86.93 \\
\hline ADL (Summary Measure) & 69.24 & - & - & - & - \\
\hline Heart & 84.08 & 94.09 & 5.91 & 4.79 & 95.21 \\
\hline Stroke & 92.24 & 97.87 & 2.13 & 10.21 & 89.79 \\
\hline CESD depression & 42.31 & - & - & - & - \\
\hline Psychological problems & 89.58 & 97.51 & 2.49 & 10.66 & 89.34 \\
\hline Cancer & 89.27 & 96.57 & 3.43 & 2.66 & 97.34 \\
\hline \multicolumn{6}{|l|}{ Behavioral and Medical Vars } \\
\hline Prescription drug use & 83.49 & 66.48 & 33.52 & 2.6 & 97.4 \\
\hline Obese & 82.35 & 93.49 & 6.51 & 14.76 & 85.24 \\
\hline Ever drinks any alcohol & 77.09 & 87.47 & 12.53 & 15.43 & 84.57 \\
\hline Smoke & 91.89 & 98.73 & 1.27 & 18.38 & 81.62 \\
\hline Arthritis & 83.35 & 87.38 & 12.62 & 3.25 & 96.75 \\
\hline Doctor use since last wave & 85.88 & 35.24 & 64.76 & 3.82 & 96.18 \\
\hline
\end{tabular}

Notes: Data come from the Health and Retirement Study, 1998-2012. Number of person-year observations is 35,319. The Within Percent is a measure of the overall stability of the variable and would be equal to $100 \%$ for time-invariant variables. It is the normalized between weighted average of the within percents for the various values taken on by a variable; the closer this value is to $100 \%$, the less variation over time there is in this variable for a given individual. The transition probabilities of interest, $\mathrm{P}\left(\mathrm{X}_{\mathrm{t}}=1 \mid \mathrm{X}_{\mathrm{t}-1}=0\right)$ and $\mathrm{P}\left(\mathrm{X}_{\mathrm{t}}=0 \mid \mathrm{X}_{\mathrm{t}-1}=1\right)$, represent probabilities of transitioning into a different state between two waves and are shown in bold. Transition probabilities are only shown for dichotomous variables. 
Appendix Table 2: Estimating the Probability of Falling with Injury (Falling Sample)

\begin{tabular}{|c|c|c|c|}
\hline VARIABLES & Limited & Extended & FE \\
\hline Male & $\begin{array}{c}-0.1138^{* * *} \\
(0.011)\end{array}$ & $\begin{array}{c}-0.1070^{* * *} \\
(0.014)\end{array}$ & \\
\hline Age & $\begin{array}{l}0.0023 \\
(0.002)\end{array}$ & $\begin{array}{l}0.0018 \\
(0.002)\end{array}$ & $\begin{array}{c}0.0034^{* *} \\
(0.002)\end{array}$ \\
\hline Number of living parents & $\begin{array}{l}-0.0107 \\
(0.018)\end{array}$ & $\begin{array}{c}-0.0045 \\
(0.019)\end{array}$ & $\begin{array}{l}0.0000 \\
(0.032)\end{array}$ \\
\hline Black non-Hispanic & & $\begin{array}{c}-0.0539 * * * \\
(0.016)\end{array}$ & \\
\hline Hispanic & & $\begin{array}{c}0.0401 * \\
(0.021)\end{array}$ & \\
\hline Other race/ethnicity & & $\begin{array}{l}0.0681 \\
(0.044)\end{array}$ & \\
\hline High school & & $\begin{array}{c}-0.0004 \\
(0.015)\end{array}$ & \\
\hline Some college & & $\begin{array}{l}0.0065 \\
(0.018)\end{array}$ & \\
\hline College & & $\begin{array}{l}0.0308 \\
(0.020)\end{array}$ & \\
\hline Married or partnered & & $\begin{array}{l}0.0394 \\
(0.033)\end{array}$ & $\begin{array}{c}-0.0575 \\
(0.086)\end{array}$ \\
\hline Divorced or separated & & $\begin{array}{l}0.0580 \\
(0.037)\end{array}$ & $\begin{array}{l}-0.0497 \\
(0.096)\end{array}$ \\
\hline Widowed & & $\begin{array}{l}0.0311 \\
(0.035)\end{array}$ & $\begin{array}{l}-0.0561 \\
(0.089)\end{array}$ \\
\hline Income & & $\begin{array}{c}-0.0001 \\
(0.000)\end{array}$ & $\begin{array}{c}-0.0002 \\
(0.000)\end{array}$ \\
\hline Income squared & & $\begin{array}{c}0.0000^{* *} \\
(0.000)\end{array}$ & $\begin{array}{l}0.0000 \\
(0.000)\end{array}$ \\
\hline Number of children & & $\begin{array}{l}-0.0007 \\
(0.003)\end{array}$ & \\
\hline Veteran status & & $\begin{array}{c}-0.0048 \\
(0.017)\end{array}$ & \\
\hline Prescription drugs & & $\begin{array}{c}0.0556^{* * *} \\
(0.017)\end{array}$ & $\begin{array}{l}0.0382 \\
(0.027)\end{array}$ \\
\hline Obese & & $\begin{array}{c}-0.0255^{* *} \\
(0.011)\end{array}$ & $\begin{array}{l}0.0014 \\
(0.022)\end{array}$ \\
\hline Alcohol (ever drink) & & $\begin{array}{c}-0.0344^{* * *} \\
(0.011)\end{array}$ & $\begin{array}{c}-0.0419 * * \\
(0.019)\end{array}$ \\
\hline Smokes now & & $\begin{array}{c}-0.0151 \\
(0.016)\end{array}$ & $\begin{array}{l}0.0283 \\
(0.035)\end{array}$ \\
\hline
\end{tabular}




\begin{tabular}{|c|c|c|c|}
\hline $\begin{array}{l}\text { Arthritis } \\
\text { Visited doctor }\end{array}$ & & $\begin{array}{c}-0.0058 \\
(0.012) \\
0.1239 * * * \\
(0.021)\end{array}$ & $\begin{array}{l}0.0106 \\
(0.030) \\
0.0558 \\
(0.034)\end{array}$ \\
\hline $\begin{array}{l}\text { Person-year observations } \\
\text { Number of individuals }\end{array}$ & 10,532 & 10,532 & $\begin{array}{c}10,532 \\
4,692\end{array}$ \\
\hline
\end{tabular}

Notes: Analysis based on 1998-2012 HRS data. Marginal effects of probit models are reported. All models include controls for Census division and year of survey. Standard errors account for clustering by person id. ${ }^{* * *}$ p-value $\leq 0.01 ; * 0.01<$ p-value $\leq 0.05 ; * 0.05<$ p-value $\leq 0.10$. 


\section{Appendix Table 3: Robustness Checks (Health Outcomes)}

\begin{tabular}{|c|c|c|c|c|c|c|}
\hline & \multicolumn{2}{|c|}{ (1) Lagged Falls } & \multicolumn{2}{|c|}{ (2) More than 1 fall } & \multicolumn{2}{|c|}{ (3) Attrition (IPW) } \\
\hline & Extended & FE & Extended & FE & Extended & FE \\
\hline Good health & $\begin{array}{c}-0.1140^{* * *} \\
(0.007)\end{array}$ & $\begin{array}{c}-0.0102^{*} \\
(0.006)\end{array}$ & $\begin{array}{c}-0.1895^{* * *} \\
(0.008)\end{array}$ & $\begin{array}{c}-0.0543^{* * *} \\
(0.006)\end{array}$ & $\begin{array}{c}-0.1390^{* * *} \\
(0.006)\end{array}$ & $\begin{array}{c}-0.0392^{* * *} \\
(0.005)\end{array}$ \\
\hline $\begin{array}{l}\text { Observations } \\
\text { Number of individuals }\end{array}$ & 27,575 & $\begin{array}{c}27,575 \\
6,835\end{array}$ & 35,290 & $\begin{array}{c}35,290 \\
7,350\end{array}$ & 35,290 & $\begin{array}{c}35,290 \\
7,350\end{array}$ \\
\hline ADL Sum & $\begin{array}{c}0.3114 * * * \\
(0.018)\end{array}$ & $\begin{array}{c}0.0443 * * * \\
(0.011)\end{array}$ & $\begin{array}{c}0.5222 * * * \\
(0.024)\end{array}$ & $\begin{array}{c}0.1965^{* * *} \\
(0.012)\end{array}$ & $\begin{array}{c}0.3517 * * * \\
(0.015)\end{array}$ & $\begin{array}{c}0.1189 * * * \\
(0.011)\end{array}$ \\
\hline $\begin{array}{l}\text { Observations } \\
\text { Number of individuals }\end{array}$ & 27,599 & $\begin{array}{c}27,599 \\
6,837\end{array}$ & 35,318 & $\begin{array}{c}35,318 \\
7,350\end{array}$ & 35,318 & $\begin{array}{c}35,318 \\
7,350\end{array}$ \\
\hline Heart disease & $\begin{array}{c}0.0706^{* * *} \\
(0.008)\end{array}$ & $\begin{array}{c}0.0069 * \\
(0.004)\end{array}$ & $\begin{array}{c}0.1030^{* * *} \\
(0.010)\end{array}$ & $\begin{array}{c}0.0179 * * * \\
(0.004)\end{array}$ & $\begin{array}{c}0.0760 * * * \\
(0.007)\end{array}$ & $\begin{array}{c}0.0105^{* * *} \\
(0.004)\end{array}$ \\
\hline $\begin{array}{l}\text { Observations } \\
\text { Number of individuals }\end{array}$ & 27,576 & $\begin{array}{c}27,576 \\
6,834\end{array}$ & 35,273 & $\begin{array}{c}35,273 \\
7,349\end{array}$ & 35,273 & $\begin{array}{c}35,273 \\
7,349\end{array}$ \\
\hline Stroke & $\begin{array}{c}0.0521^{* * *} \\
(0.005)\end{array}$ & $\begin{array}{c}0.0114 * * * \\
(0.003)\end{array}$ & $\begin{array}{c}0.0730 * * * \\
(0.007)\end{array}$ & $\begin{array}{c}0.0209 * * * \\
(0.003)\end{array}$ & $\begin{array}{c}0.0559 * * * \\
(0.005)\end{array}$ & $\begin{array}{c}0.0176^{* * *} \\
(0.003)\end{array}$ \\
\hline $\begin{array}{l}\text { Observations } \\
\text { Number of individuals }\end{array}$ & 27,591 & $\begin{array}{c}27,591 \\
6,836\end{array}$ & 35,305 & $\begin{array}{c}35,305 \\
7,350\end{array}$ & 35,305 & $\begin{array}{c}35,305 \\
7,350\end{array}$ \\
\hline Depression (CESD) & $\begin{array}{c}0.4746^{* * *} \\
(0.033)\end{array}$ & $\begin{array}{l}0.0247 \\
(0.023)\end{array}$ & $\begin{array}{c}0.7440^{* * *} \\
(0.040)\end{array}$ & $\begin{array}{c}0.1901 * * * \\
(0.026)\end{array}$ & $\begin{array}{c}0.5597 * * * \\
(0.029)\end{array}$ & $\begin{array}{c}0.1267 * * * \\
(0.021)\end{array}$ \\
\hline $\begin{array}{l}\text { Observations } \\
\text { Number of individuals }\end{array}$ & 26,100 & $\begin{array}{c}26,100 \\
6,552\end{array}$ & 33,223 & $\begin{array}{c}33,223 \\
7,082\end{array}$ & 33,223 & $\begin{array}{c}33,223 \\
7,082\end{array}$ \\
\hline Psychological problems & $\begin{array}{c}0.0956^{* * *} \\
(0.007)\end{array}$ & $\begin{array}{c}0.0117 * * * \\
(0.003)\end{array}$ & $\begin{array}{c}0.1358^{* * * *} \\
(0.008)\end{array}$ & $\begin{array}{c}0.0240 * * * \\
(0.004)\end{array}$ & $\begin{array}{c}0.1014 * * * \\
(0.006)\end{array}$ & $\begin{array}{c}0.0202^{* * *} \\
(0.003)\end{array}$ \\
\hline $\begin{array}{l}\text { Observations } \\
\text { Number of individuals }\end{array}$ & 27,574 & $\begin{array}{c}27,574 \\
6,835\end{array}$ & 35,264 & $\begin{array}{c}35,264 \\
7,350\end{array}$ & 35,264 & $\begin{array}{c}35,264 \\
7,350\end{array}$ \\
\hline
\end{tabular}


Notes: Analysis based on 1998-2012 HRS data. All models include controls for gender, age, number of living parents, race/ethnic status, education, marital status, income, number of children, veteran status, use of prescription drugs, obesity, alcohol consumption, smoking status, arthritis, physician use, year of survey, and Census division. Standard errors account for clustering by person id. *** $\mathrm{p}$ value $\leq 0.01 ; * * 0.01<$ p-value $\leq 0.05 ; * 0.05<$ p-value $\leq 0.10$. 


\section{Appendix Table 4: Stratified Samples (Health Outcomes)}

\begin{tabular}{|c|c|c|c|c|c|c|}
\hline & \multicolumn{2}{|c|}{ (1) Gender } & \multicolumn{2}{|c|}{ (2) Marital Status } & \multicolumn{2}{|c|}{ (3) Age Group } \\
\hline & Male & Female & Married & $\begin{array}{c}\text { Not } \\
\text { Married }\end{array}$ & $60-69$ & $70+$ \\
\hline Good health & $\begin{array}{c}-0.1485^{* * *} \\
(0.010)\end{array}$ & $\begin{array}{c}-0.1319 * * * \\
(0.008)\end{array}$ & $\begin{array}{c}-0.1352^{* * *} \\
(0.008)\end{array}$ & $\begin{array}{c}-0.1433^{* * *} \\
(0.010)\end{array}$ & $\begin{array}{c}-0.1282^{* * *} \\
(0.009)\end{array}$ & $\begin{array}{c}-0.1456^{* * *} \\
(0.008)\end{array}$ \\
\hline Observations & 15,647 & 19,643 & 22,970 & 12,320 & 15,050 & 20,240 \\
\hline ADL Sum & $\begin{array}{c}0.3420^{* * *} \\
(0.023)\end{array}$ & $\begin{array}{c}0.3578 * * * \\
(0.021)\end{array}$ & $\begin{array}{c}0.3129 * * * \\
(0.018)\end{array}$ & $\begin{array}{c}0.4141 * * * \\
(0.028)\end{array}$ & $\begin{array}{c}0.3328^{* * *} \\
(0.020)\end{array}$ & $\begin{array}{c}0.3644 * * * \\
(0.020)\end{array}$ \\
\hline Observations & 15,659 & 19,659 & 22,989 & 12,329 & 15,056 & 20,262 \\
\hline Heart disease & $\begin{array}{c}0.0595^{* * *} \\
(0.012)\end{array}$ & $\begin{array}{c}0.0883^{* * *} \\
(0.009)\end{array}$ & $\begin{array}{c}0.0682 * * * \\
(0.009)\end{array}$ & $\begin{array}{c}0.0893 * * * \\
(0.011)\end{array}$ & $\begin{array}{c}0.0764 * * * \\
(0.009)\end{array}$ & $\begin{array}{c}0.0747 * * * \\
(0.009)\end{array}$ \\
\hline Observations & 15,639 & 19,634 & 22,963 & 12,310 & 15,027 & 20,246 \\
\hline Stroke & $\begin{array}{c}0.0633^{* * *} \\
(0.008)\end{array}$ & $\begin{array}{c}0.0508^{* * *} \\
(0.006)\end{array}$ & $\begin{array}{c}0.0558 * * * \\
(0.006)\end{array}$ & $\begin{array}{c}0.0561 * * * \\
(0.007)\end{array}$ & $\begin{array}{c}0.0583^{* * *} \\
(0.006)\end{array}$ & $\begin{array}{c}0.0544 * * * \\
(0.006)\end{array}$ \\
\hline Observations & 15,654 & 19,651 & 22,983 & 12,322 & 15,049 & 20,256 \\
\hline Depression (CESD) & $\begin{array}{c}0.4820 * * * \\
(0.043)\end{array}$ & $\begin{array}{c}0.6101 * * * \\
(0.040)\end{array}$ & $\begin{array}{c}0.4761 * * * \\
(0.033)\end{array}$ & $\begin{array}{c}0.6808 * * * \\
(0.054)\end{array}$ & $\begin{array}{c}0.5481 \text { *** } \\
(0.041)\end{array}$ & $\begin{array}{c}0.5654 * * * \\
(0.035)\end{array}$ \\
\hline Observations & 14,166 & 19,057 & 21,388 & 11,835 & 14,102 & 19,121 \\
\hline Psychological problems & $\begin{array}{c}0.0695 * * * \\
(0.009)\end{array}$ & $\begin{array}{c}0.1244 * * * \\
(0.009)\end{array}$ & $\begin{array}{c}0.0825 * * * \\
(0.007)\end{array}$ & $\begin{array}{c}0.1306 * * * \\
(0.011)\end{array}$ & $\begin{array}{c}0.0975^{* * *} \\
(0.008)\end{array}$ & $\begin{array}{c}0.1036 * * * \\
(0.007)\end{array}$ \\
\hline Observations & 15,634 & 19,630 & 22,959 & 12,305 & 15,025 & 20,239 \\
\hline
\end{tabular}

Notes: Analysis based on 1998-2012 HRS data. All models include controls for gender, age, number of living parents, race/ethnic status, education, marital status, income, number of children, veteran status, use of prescription drugs, obesity, alcohol consumption, smoking status, arthritis, physician use, year of survey, and Census division. Standard errors account for clustering by person id. Results in bold indicate that the difference in coefficients between the two categories is statistically significant at the $5 \%$ level. *** p-value $\leq 0.01 ; * * 0.01<$ p-value $\leq 0.05 ; * 0.05<$ p-value $\leq 0.10$. 


\section{Appendix Table 5: Nonlinear Effects for Number of Falls}

\section{(Table 4 Including Quadratic Term)}

\begin{tabular}{|c|c|c|c|c|c|}
\hline & Limited & Extended & $\mathrm{FE}$ & Lewbel IV & $\begin{array}{c}\text { Lewbel IV } \\
\text { FE }\end{array}$ \\
\hline \multicolumn{6}{|l|}{ Good health } \\
\hline \multirow[t]{2}{*}{ Fall } & $-0.0552 * * *$ & $-0.0450 * * *$ & $-0.0149 * * *$ & $-0.0491 * *$ & $-0.0275^{* * *}$ \\
\hline & $(0.002)$ & $(0.002)$ & $(0.001)$ & $(0.019)$ & (0.011) \\
\hline \multirow{2}{*}{ Fall Squared } & $0.0010^{* * *}$ & $0.0008^{* * *}$ & $0.0003 * * *$ & $0.0011^{* *}$ & $0.0006^{* *}$ \\
\hline & $(0.000)$ & $(0.000)$ & $(0.000)$ & $(0.001)$ & $(0.000)$ \\
\hline \multirow{3}{*}{$\begin{array}{l}\text { Observations } \\
\text { Number of individuals }\end{array}$} & 35,290 & 35,290 & 35,290 & 35,290 & 34,830 \\
\hline & & & 7,350 & & 6,890 \\
\hline & 0.040 & 0.184 & 0.033 & 0.038 & 0.025 \\
\hline \multirow{4}{*}{$\begin{array}{l}\text { Effect at mean } \\
\text { Effect at mean p-value } \\
\text { F-stat (IV) } \\
\text { Sargan pval (IV) }\end{array}$} & -0.0535 & -0.0436 & -0.0144 & -0.0473 & -0.0265 \\
\hline & 0 & 0 & 0 & $3.69 \mathrm{e}-06$ & 0.00280 \\
\hline & & & & 52.91 & 54.49 \\
\hline & & & & 0.196 & 0.00123 \\
\hline \multicolumn{6}{|l|}{$A D L$ Sum } \\
\hline \multirow[t]{2}{*}{ Fall } & $0.1408^{* * *}$ & $0.1289 * * *$ & $0.0612^{* * *}$ & $0.1059 * *$ & $0.2280 * * *$ \\
\hline & $(0.007)$ & $(0.007)$ & $(0.003)$ & $(0.053)$ & $(0.022)$ \\
\hline \multirow{2}{*}{ Fall Squared } & $-0.0025 * * *$ & $-0.0022^{* * *}$ & $-0.0010^{* * *}$ & -0.0019 & $-0.0047 * * *$ \\
\hline & $(0.000)$ & $(0.000)$ & $(0.000)$ & $(0.001)$ & $(0.001)$ \\
\hline \multirow{3}{*}{$\begin{array}{l}\text { Observations } \\
\text { Number of individuals }\end{array}$} & 35,318 & 35,318 & 35,318 & 35,318 & 34,861 \\
\hline & & & 7,350 & & 6,893 \\
\hline & 0.074 & 0.130 & 0.060 & 0.070 & -0.061 \\
\hline \multirow{4}{*}{$\begin{array}{l}\text { Effect at mean } \\
\text { Effect at mean p-value } \\
\text { F-stat (IV) } \\
\text { Sargan pval (IV) }\end{array}$} & 0.137 & 0.125 & 0.0595 & 0.103 & 0.220 \\
\hline & 0 & 0 & 0 & $1.36 \mathrm{e}-07$ & 0 \\
\hline & & & & 50.83 & 52 \\
\hline & & & & 0.0277 & 0 \\
\hline \multicolumn{6}{|l|}{ Heart disease } \\
\hline \multirow[t]{2}{*}{ Fall } & $0.0316^{* * *}$ & $0.0243 * * *$ & $0.0067 * * *$ & $0.0371 *$ & 0.0120 \\
\hline & $(0.002)$ & $(0.002)$ & $(0.001)$ & $(0.020)$ & $(0.008)$ \\
\hline \multirow[t]{2}{*}{ Fall Squared } & $-0.0006 * * *$ & $-0.0005^{* * *}$ & $-0.0001 * * *$ & $-0.0009 *$ & -0.0003 \\
\hline & $(0.000)$ & $(0.000)$ & $(0.000)$ & $(0.001)$ & $(0.000)$ \\
\hline \multirow{3}{*}{$\begin{array}{l}\text { Observations } \\
\text { Number of individuals }\end{array}$} & 35,273 & 35,273 & 35,273 & 35,273 & 34,813 \\
\hline & & & 7,349 & & 6,889 \\
\hline & 0.031 & 0.082 & 0.072 & 0.030 & 0.065 \\
\hline \multirow{3}{*}{$\begin{array}{l}\text { Effect at mean } \\
\text { Effect at mean p-value } \\
\text { F-stat (IV) }\end{array}$} & 0.0305 & 0.0234 & 0.00644 & 0.0356 & 0.0115 \\
\hline & 0 & 0 & $4.24 \mathrm{e}-09$ & 0.0727 & 0.171 \\
\hline & & & & 52.83 & 53.01 \\
\hline
\end{tabular}




\begin{tabular}{|c|c|c|c|c|c|}
\hline Sargan pval (IV) & & & & 0.0114 & 0.221 \\
\hline \multicolumn{6}{|l|}{ Stroke } \\
\hline \multirow[t]{2}{*}{ Fall } & $0.0203 * * *$ & $0.0183 * * *$ & $0.0069 * * *$ & 0.0157 & $0.0234 * * *$ \\
\hline & $(0.002)$ & $(0.002)$ & (0.001) & $(0.017)$ & $(0.005)$ \\
\hline \multirow{2}{*}{ Fall Squared } & $-0.0003 * * *$ & $-0.0003 * * *$ & $-0.0001 * * *$ & -0.0002 & $-0.0005^{* * *}$ \\
\hline & $(0.000)$ & $(0.000)$ & $(0.000)$ & $(0.000)$ & $(0.000)$ \\
\hline \multirow{3}{*}{$\begin{array}{l}\text { Observations } \\
\text { Number of individuals }\end{array}$} & 35,305 & 35,305 & 35,305 & 35,305 & 34,847 \\
\hline & & & 7,350 & & 6,892 \\
\hline & 0.022 & 0.041 & 0.033 & 0.021 & 0.012 \\
\hline \multirow{4}{*}{$\begin{array}{l}\text { Effect at mean } \\
\text { Effect at mean p-value } \\
\text { F-stat (IV) } \\
\text { Sargan pval (IV) }\end{array}$} & 0.0197 & 0.0178 & 0.00665 & 0.0153 & 0.0226 \\
\hline & 0 & 0 & 0 & 0.00134 & $1.38 \mathrm{e}-10$ \\
\hline & & & & 50.82 & 52.01 \\
\hline & & & & 0.752 & 0.366 \\
\hline \multicolumn{6}{|l|}{ Depres } \\
\hline \multirow{2}{*}{ Fall } & $0.2143^{* * *}$ & $0.1808^{* * *}$ & $0.0525^{* * *}$ & $0.2019 * * *$ & $0.0953^{* *}$ \\
\hline & $(0.012)$ & $(0.011)$ & $(0.007)$ & $(0.070)$ & $(0.039)$ \\
\hline \multirow{2}{*}{ Fall Squared } & $-0.0040 * * *$ & $-0.0032^{* * *}$ & $-0.0008^{* * *}$ & $-0.0042^{* *}$ & $-0.0019 * *$ \\
\hline & $(0.000)$ & $(0.000)$ & $(0.000)$ & $(0.002)$ & $(0.001)$ \\
\hline \multirow{3}{*}{$\begin{array}{l}\text { Observations } \\
\text { Number of individuals }\end{array}$} & 33,223 & 33,223 & 33,223 & 33,223 & 32,676 \\
\hline & & & 7,082 & & 6,535 \\
\hline & 0.047 & 0.140 & 0.010 & 0.046 & 0.003 \\
\hline \multirow{4}{*}{$\begin{array}{l}\text { Effect at mean } \\
\text { Effect at mean p-value } \\
\text { F-stat (IV) } \\
\text { Sargan pval (IV) }\end{array}$} & 0.208 & 0.175 & 0.0511 & 0.195 & 0.0921 \\
\hline & 0 & 0 & 0 & $7.46 \mathrm{e}-06$ & 0.00346 \\
\hline & & & & 85.69 & 71.21 \\
\hline & & & & 0.000107 & 0.0449 \\
\hline \multicolumn{6}{|l|}{ Psych. problems } \\
\hline \multirow{2}{*}{ Fall } & $0.0388^{* * *}$ & $0.0325^{* * *}$ & $0.0075^{* * *}$ & $0.0426^{* *}$ & $0.0243 * * *$ \\
\hline & $(0.002)$ & $(0.002)$ & $(0.001)$ & $(0.018)$ & $(0.006)$ \\
\hline \multirow[t]{2}{*}{ Fall Squared } & $-0.0007 * * *$ & $-0.0006^{* * *}$ & $-0.0001 * * *$ & $-0.0010^{* *}$ & $-0.0005^{* * *}$ \\
\hline & $(0.000)$ & $(0.000)$ & $(0.000)$ & $(0.000)$ & $(0.000)$ \\
\hline \multirow{3}{*}{$\begin{array}{l}\text { Observations } \\
\text { Number of individuals }\end{array}$} & 35,264 & 35,264 & 35,264 & 35,264 & 34,803 \\
\hline & & & 7,350 & & 6,889 \\
\hline & 0.049 & 0.096 & 0.009 & 0.047 & -0.007 \\
\hline \multirow{4}{*}{$\begin{array}{l}\text { Effect at mean } \\
\text { Effect at mean p-value } \\
\text { F-stat (IV) } \\
\text { Sargan pval (IV) }\end{array}$} & 0.0377 & 0.0316 & 0.00735 & 0.0410 & 0.0234 \\
\hline & 0 & 0 & 0 & 0.00471 & $2.97 \mathrm{e}-05$ \\
\hline & & & & 50.22 & 50.50 \\
\hline & & & & 0.00548 & 0.00940 \\
\hline $\begin{array}{l}\text { Cancer } \\
\text { Fall }\end{array}$ & $0.0045^{* *}$ & $0.0033^{*}$ & $0.0026 * * *$ & -0.0186 & -0.0045 \\
\hline
\end{tabular}




\begin{tabular}{|l|ccccc|} 
& $(0.002)$ & $(0.002)$ & $(0.001)$ & $(0.014)$ & $(0.006)$ \\
Fall Squared & -0.0000 & -0.0000 & $-0.0001 * * *$ & 0.0005 & 0.0001 \\
& $(0.000)$ & $(0.000)$ & $(0.000)$ & $(0.000)$ & $(0.000)$ \\
Observations & & & & & \\
Number of individuals & 35,295 & 35,295 & 35,295 & 35,295 & 34,837 \\
& & & 7,350 & & 6,892 \\
Effect at mean & 0.012 & 0.024 & 0.062 & 0.003 & 0.057 \\
Effect at mean p-value & 0.00450 & 0.00333 & 0.00244 & -0.0177 & -0.00434 \\
F-stat (IV) & 0.00541 & 0.0264 & 0.00862 & 0.350 & 0.723 \\
Sargan pval (IV) & & & & 51.15 & 52.43 \\
\hline
\end{tabular}

Notes: Analysis based on 1998-2012 HRS data. Limited models include controls for gender, age, and number of living parents. Extended models include controls for gender, age, number of living parents, race/ethnic status, education, marital status, income, number of children, veteran status, use of prescription drugs, obesity, alcohol consumption, smoking status, arthritis, physician use, year of survey, and Census division. Standard errors account for clustering by person id. *** p-value $\leq$ $0.01 ; * * 0.01<$ p-value $\leq 0.05 ; * 0.05<$ p-value $\leq 0.10$. 
Figure 1: Proposed Mechanisms

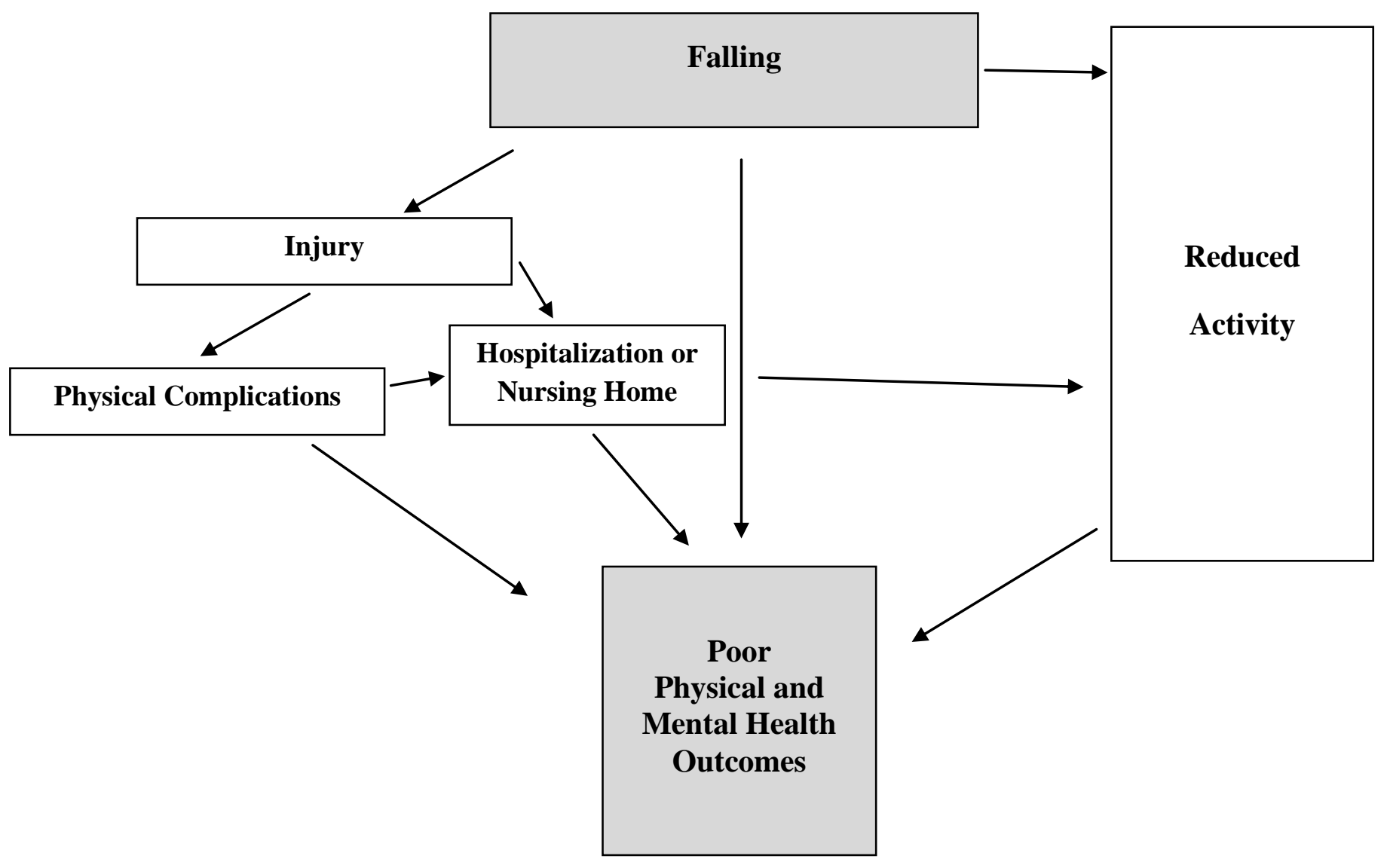


Figure 2: Fatal Falls, Ages 65+, United States

$=$

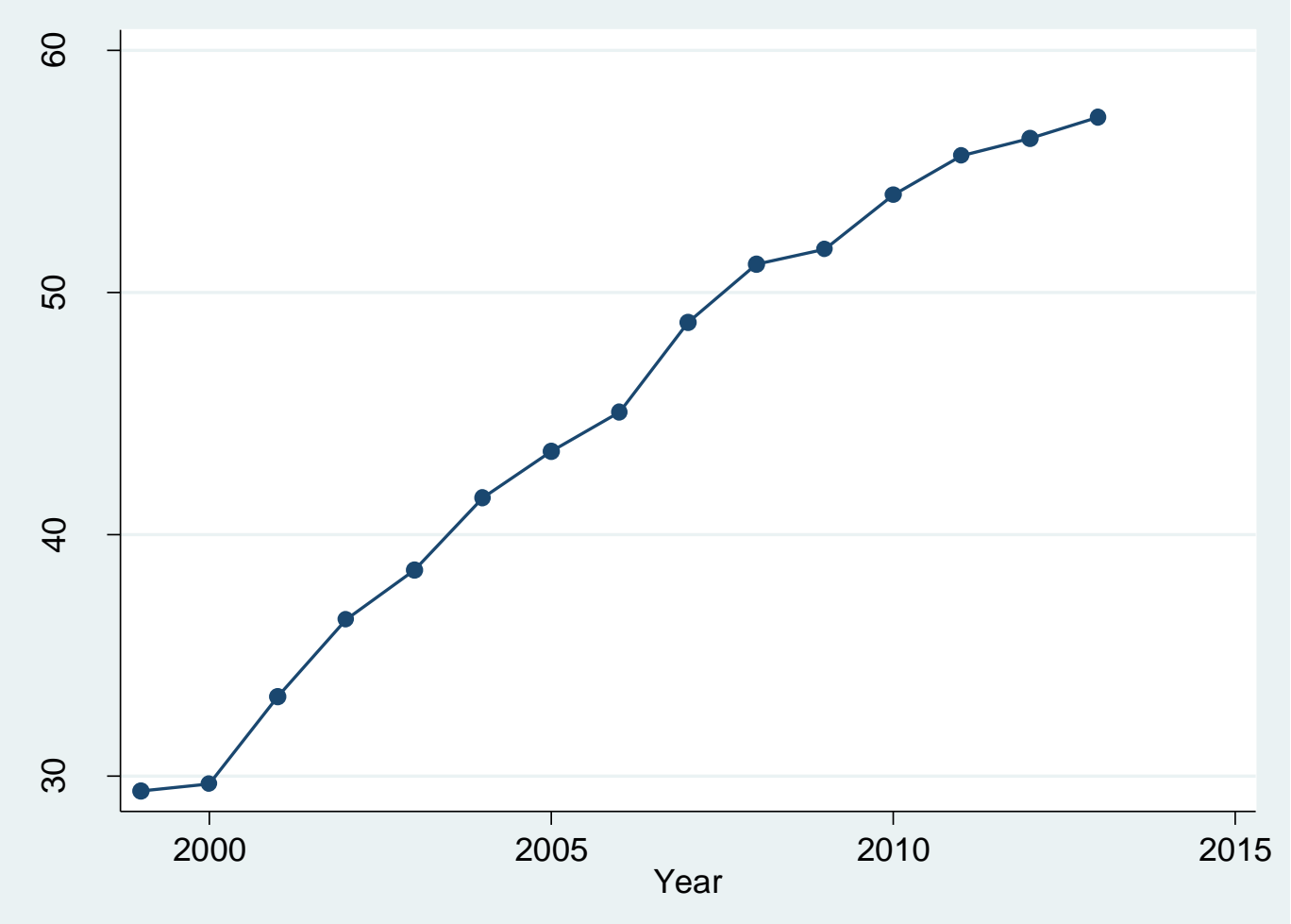

Notes: Fall data obtained from WISQARS. See text for more detail. 
Figure 3: Nonfatal Falls, Ages 65+, United States

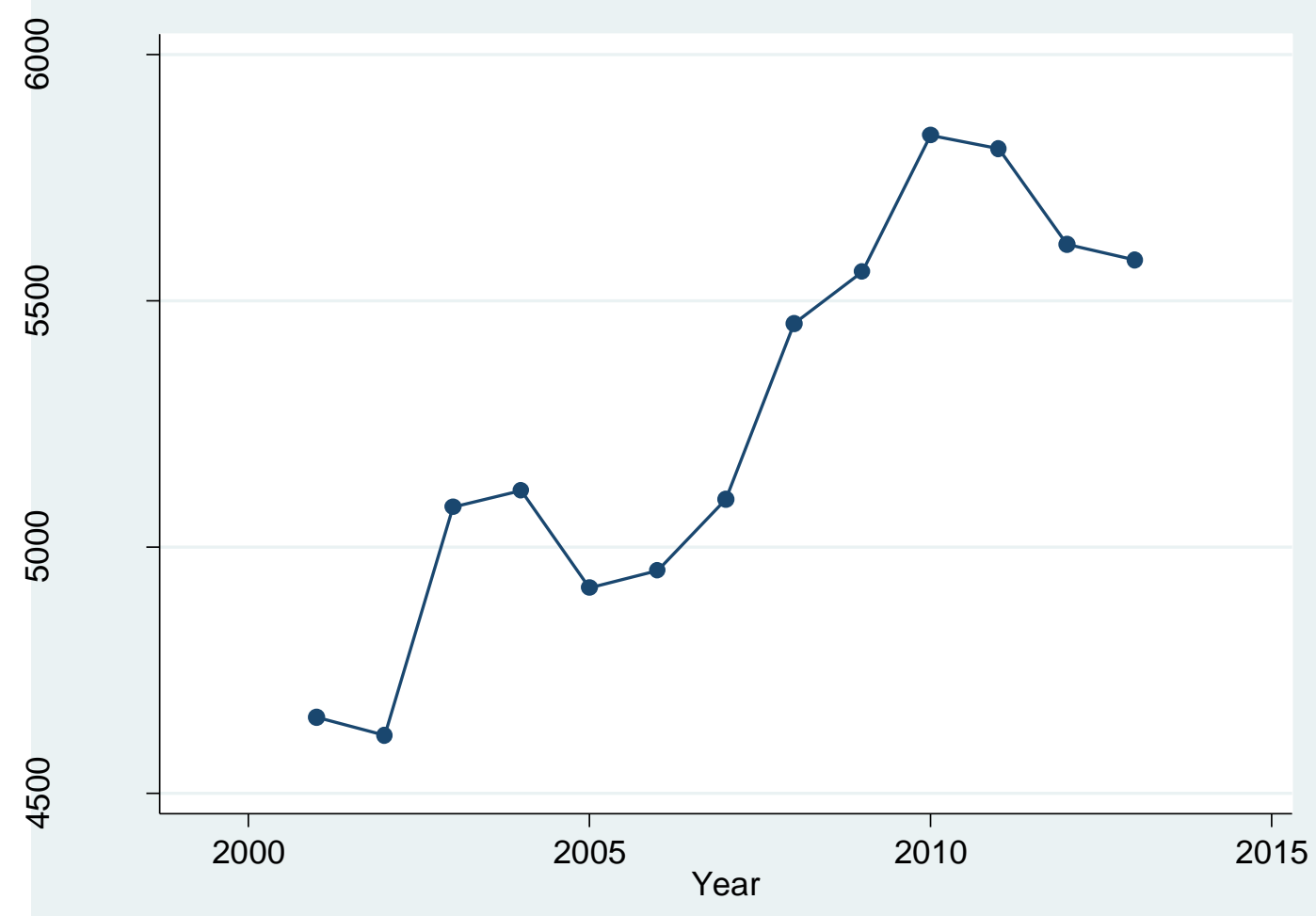

Notes: Fall data obtained from WISQARS. See text for more detail. 
Figure 4a: List of State Assistance Programs for Home Modifications in Various States, 2016

\begin{tabular}{|l|l|}
\hline Alaska & Nevada \\
Senior Access Program & COPE \\
Alzheimers Disease Related Dementias Mini-Grants & Assistive Technology for Independent Living \\
Arizona & New Jersey \\
Non-Medical HCBS & New Jersey Assistance for Community Caregiving \\
Connecticut & New York \\
Home Care for Elders & Expanded In-home Services for the Elderly \\
Choices at Home Project & RESTORE Program \\
Florida & North Dakota \\
Community Care for the Elderly (CCE) & SPED \\
Home Care for the Elderly (HC) & Ohio \\
Georgia & Elderly Services Program \\
Non Medicaid HCBS & Pennsylvania \\
Illinois & Pennsylvania Assistive Technology Foundation \\
Illinois Housing Home Modification Program & Access Home Modification Program \\
Indiana & Options Program \\
CHOICES & Rhode Island \\
Iowa & Home and Community Care Co-Pay Program \\
Iowa Able Foundation Loan Program & Texas \\
Senior Living / Case Management Program & DADS Services to Assist Independent Living \\
Kentucky & In-Home and Family Support \\
Hart-Supported Living Program & Utah \\
Maine & The Alternatives Program \\
Maine Home Repair and Elderly Grant & Vermont \\
Maine Caregiver Respite & Home Access Program \& Sue Williams Freedom \\
Maryland & Fund \\
Accessible Homes for Seniors & Washington DC \\
Massachusetts & Senior Citizens' Home Repair and Improvement \\
Massachusetts Home Care and Enhanced & Wisconsin \\
Community Options Programs & AFCSP \\
Minnesota & Community Options Program (COP) \\
Alternative Care & SSI Exceptional Expense Supplement \\
Consumer Support Grant & Family Care and Family Care Partnership \\
Nebraska & \\
Assistive Technology/Home Modifications Service & \\
Disabled Persons and Family Support & \\
\hline & \\
\hline
\end{tabular}

Source: http://www.payingforseniorcare.com/home-modifications/state-assistance-programs.html. 
Figure 4b: Map of Home Modification Programs in Various States, 2016

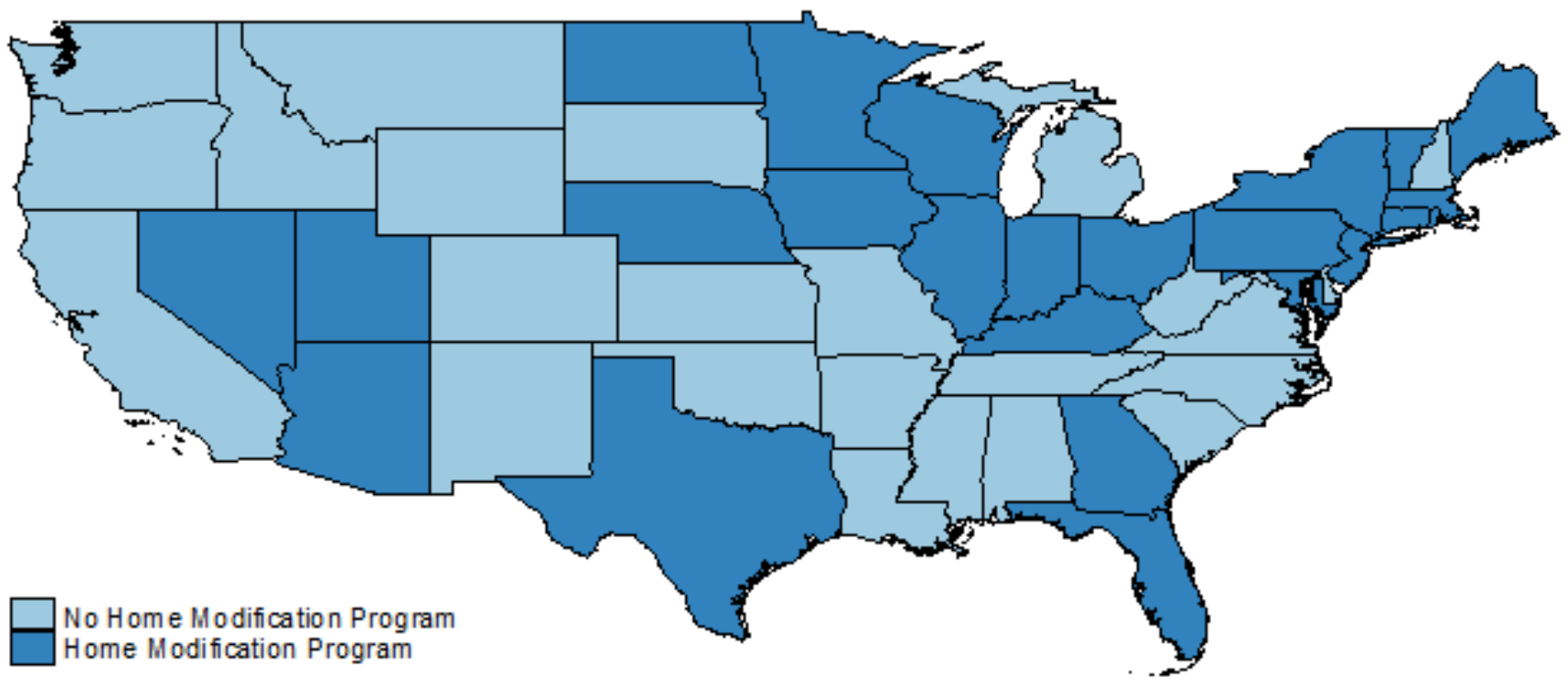

Note: Alaska has two home modification programs, while Hawaii does not appear to have any. Data for map obtained from http://www.payingforseniorcare.com/home-modifications/state-assistanceprograms.html. 